\title{
Funções, estruturação e evolução das crenças (e conhecimentos) dos professores $^{1}$
}

\author{
Marcel Crahay* \\ Philippe Wanlin** \\ Élisabeth Issaieva***

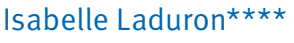

*(Universidade

Genebra, Genebra,

de Suíça)

**(Universidade de Genebra, Genebra, Suíça)

***(Universidade de Genebra, Genebra, Suíça)

$\star \star \star \star$ (Universidade de Liège, Liège, Bélgica) de Resumo: Sintetizando as principais contribuições dos estudos sobre as crenças e os conhecimentos dos professores, este artigo aborda uma das problemáticas ligadas à formação docente: as crenças e conhecimentos dos professores evoluem? De que maneira? Em quais condições? Para responder a essas perguntas, apresentamos diversas correntes de pesquisa: as que tratam das mudanças ditas "naturais"; aquelas sobre as fases de desenvolvimento do docente; os estudos que verificam os efeitos dos programas de formação de professores; as pesquisas que evidenciam o desenvolvimento da equipe, além dos estudos sobre as crenças dos professores iniciantes. Após a apresentação das pesquisas existentes, discutimos a constatação da dificuldade da evolução das crenças dos professores, levantando várias hipóteses para explicar a impermeabilidade relativa dessas crenças aos processos formativos.

Palavras-chave: Saberes. Desenvolvimento de capacidades profissionais. Professor estagiário. Prática pedagógica. Formação de professores.

Originalmente publicado na Revue Française de Pédagogie (n. 172, p. 85-129, jul./set. 2010), com o título “Fonctions, structuration et évolution des croyances (et connaissances) des enseignants”. Traduzido e publicado com autorização. Tradução de Jaci Brasil Tonelli e revisão técnica de Elba Siqueira de Sá Barretto. 


\section{INTRODUÇÃO}

A maioria dos estudos empíricos acerca do que pensam os professores sobre o ensino e a aprendizagem está publicada em revistas anglófonas. Nessa esfera cultural, o termo crença (belief) se impôs, ao passo que, na literatura francófona, o termo “representação" é privilegiado. A bem da verdade, seja ela anglófona ou francófona, na literatura de pesquisa há abundância de termos diferentes: teorias pessoais, perspectivas, concepções, preconcepções, teorias implícitas, percepções, atitudes, disposições... Ainda que esses termos tenham definições diferentes, é difícil diferenciá-los. Em sua revisão da literatura, Pajares (1992) as considera, aliás, como intercambiáveis².

A dificuldade de definir o conceito de crença é amplamente reconhecida. Discutindo esse problema, Pajares (1992) menciona várias definições; ele destaca duas que, sendo complementares, lhe parecem prototípicas de duas tendências diferentes, detectáveis no conjunto das produções dos pesquisadores. A primeira definição remete a "toda proposição simples, consciente ou inconsciente inferida a partir do que uma pessoa diz ou faz, podendo ser precedida pela frase 'eu acredito que..."” (ROKEACH ${ }^{3}, 1976$, apud PAJARES, 1992, p. 314). A segunda vê a crença como "uma representação que um indivíduo faz da realidade; essa possui bastante validade, verdade ou credibilidade para guiar o pensamento e o comportamento" (HARVEY4, 1986, apud PAJARES, 1992, p. 313). Se a primeira definição é estritamente operacional5 , a segunda remete à ideia de "alguma coisa" de ordem cognitiva mobilizada pelos professores em certas circunstâncias, e que veicula um conteúdo relacionado à experiência de ensino. Podemos considerar que essa propriedade - um conteúdo relativo ao ensino - constitui o núcleo duro, sendo assim um consenso de todas as pesquisas reagrupadas sob o rótulo crenças

Há aqui uma tomada de posição pouco cômoda; ela se justifica, contudo, na medida em que, além das diferenças terminológicas, uma corrente de pesquisa relativa aos professores trata das "construções mentais da experiência - frequentemente condensadas e integradas em esquemas ou conceitos" (SIGEL, 1985, p. 351). De nossa parte, utilizaremos prioritariamente o termo "crença", mas também "concepção", considerando-o como sinônimo de crença.

ROKEACH, M. Beliefs, attitudes and values: A theory of organization and change. San Francisco: Jossey-Bass, 1976.

HARVEY, O. Belief systems and attitudes toward the death penalty and other punishments. Journal of Personality, v. 54, n. 4, p. 659-675, 1986.

Ressaltemos, entretanto, que alguns autores contestam radicalmente o caráter essencialmente proposicional das crenças (cf. em especial CALDERHEAD, 1996). Retornaremos a esse ponto. 
dos professores (teacher's beliefs) ${ }^{6}$. Nessa fase de reflexão, podemos então considerar que o conceito de crenças dos professores remete a conteúdos mentais, relacionados ao ensino, compilados em esquemas ou conceitos, podendo tomar a forma de proposições ou asserções.

Alguns autores (FENSTERMACHER, 1979; HOFER; PINTRICH, 1997; NESPOR, 1987) tentaram esclarecer a distinção entre crenças (beliefs) e conhecimentos (knowledges), especialmente para mostrar que há uma diferença de status epistêmico entre os dois termos. Os conhecimentos supõem um acordo entre as mentes - um acordo intersubjetivo - fundado sobre um conjunto de provas e/ou argumentos que permitem justificar a validade das proposições retidas ou, ao menos, suas maiores verossimilhanças em relação a outras concepções relativas ao mesmo objeto ou ao mesmo fenômeno. Por extensão, podemos considerar que, em princípio, as crenças não pressupõem um acordo intersubjetivo que repousa sobre um sistema de validação rigoroso ${ }^{7}$. Certamente muitas crenças são amplamente compartilhadas no seio de determinados grupos sociais, mas sua evidência se sustenta mais no fato de que elas são difundidas e não contestadas do que no fato de que elas foram provadas ou justificadas por uma argumentação rigorosa. Se a maioria das crenças é de origem social, elas implicam uma adesão individual que os professores assinalam, por exemplo, afirmando: “Eu sei que as pesquisas concluem sobre o efeito negativo da reprovação, mas creio que a reprovação pode ser útil às vezes" (MARCOUX; CRAHAY, 2008). Assim as crenças dos professores englobariam ao mesmo tempo elementos pessoais e elementos compartilhados pelo conjunto da comunidade docente (VERLOOP; VAN DRIEL; MEIJER, 2001). Elas podem ser consideradas como uma característica psicológica do indivíduo, estando enraizadas no substrato

6 Essa propriedade permite distinguir o domínio dos teachers' beliefs and knowledge da corrente de pesquisa designada pela expressão teacher thinking. As pesquisas próprias dessa corrente tratam principalmente do processo de planejamento das aulas (teacher planning), de decisão ou de modulação da ação em sala de aula (interactive decision making), assim como daquele de reflexão a posteriori (post-active reflecting). Certamente, existem sobreposições importantes entre esses dois campos de pesquisa. É evidente que os professores mobilizam crenças quando planejam uma aula ou tomam uma decisão interativa, mas a prioridade é diferente: em um caso, refere-se ao conteúdo; em outro, ao processo.

7 Em seu Vocabulaire technique et critique de la philosophie, Lalande (2002) assinala que o termo "crença” tomou, em filosofia, um sentido particular desde Kant, que propõe utilizá-lo "quando o consentimento é suficiente apenas do ponto de vista subjetivo e que ele é tomado como insuficiente do ponto de vista objetivo" (p. 198). Assim, parafraseando Kant, poderíamos dizer que a crença se caracteriza por um consentimento forte e, em determinado número de casos, por um consentimento objetivo fraco, quiçá insuficiente. 
cultural. Isso permite, segundo nossa perspectiva, aproximar esse conceito do de representação e, mais fundamentalmente, considerar as crenças e representações como construções ao mesmo tempo cognitivas e sociais. Em outras palavras, as crenças, ou ainda, as representações dos professores têm uma natureza dupla, indissociavelmente individual e social. Isso não significa que todos os professores compartilham crenças idênticas, nem que eles agem de maneira comum de acordo com um corpus indiscriminado de crenças. Pesquisas (HALKES; DEIJKERS, 2003; MUNBY, 1983) revelam, da parte de diferentes professores, um recurso idiossincrático aos conhecimentos e às crenças para selecionar os atos de ensino, controlar seus processos e avaliar seus efeitos. Outras pesquisas indicam um recurso às orientações profissionais ou a perfis de crenças ou de cognições diferentes segundo os professores, culminando em comportamentos instrucionais heterogêneos (BUCHMANN, 1986, 1987).

Nas publicações da área, parece igualmente que as fronteiras entre conhecimentos e crenças são dificilmente identificáveis, o que leva um bom número de especialistas a tratar esses dois termos de maneira concomitante (BORKO; PUTNAM, 1996; CALDERHEAD, 1996; FENSTERMACHER, 1994; PAJARES, 1992; VAUSE, 2009; WOOLFOLK HOY; DAVIS; PAPE, 2006), e até mesmo a estimar que seria mais sensato considerar os saberes dos professores como sendo, essencialmente, crenças (KAGAN, 1992). Reteremos desses trabalhos a ideia de que os conhecimentos fariam mais referência a elementos factuais ou empíricos, enquanto que as crenças remeteriam, sobretudo, a suposições ou ideologia ${ }^{8}$, sendo ambos, ideias e conhecimentos, fortemente marcados pelas experiências pessoais e coletivas dos professores.

Em um artigo rico em reflexões, Kagan (1992) propõe considerar as crenças dos professores como uma forma de conhecimento pessoal, composta de

Entretanto, na terceira edição do Handbook of research on teacher education, a associação entre os termos "crenças" e "conhecimentos" desaparece em proveito da noção de "capacidade" (capacity), que agrupa esses dois termos combinando-os com os traços de personalidade dos professores, suas atitudes, suas competências e suas percepções quanto à sua competência pessoal (GRANT, 2008; GRANT; AGOSTO, 2008; HOWARD; ALEMAN, 2008; MCDIARMID; CLEVENGER-BRIGHT, 2008). Não se deve compreender o termo capacity como a capacidade tal qual definida por De Landsheere (1979), mas, sobretudo, como remetendo a um conteúdo cognitivo ou àquele que poderíamos qualificar como "faculdades" ou "cognições". Além disso, os autores atuais insistem sobre o fato de que a noção de capacidade (ou cognição) é evolutiva, pois sugere certa possibilidade da parte dos professores de continuar desenvolvendo seus conhecimentos, crenças e competências através do tempo (McDIARMID; CLEVENGERBRIGHT, 2008). 
conjecturas, muitas vezes implícitas, referentes aos alunos, à aprendizagem, à turma, aos processos de ensino e aos objetos a ensinar ${ }^{9}$. Para a autora, que retoma as teses de Broudy (1980), de Floden (1988) e de Lieberman (1992), convém reconhecer que o ensino é um domínio caracterizado pela ausência quase total de verdades, de certezas ou de conhecimentos cientificamente estabelecidos sobre a boa maneira de ensinar ${ }^{10}$. É, portanto, normal que os professores adotem uma pedagogia pessoal. Essa última mistura elementos tirados da própria experiência do professor, outros inspirados no senso comum da comunidade docente ou, mais amplamente, da comunidade cultural à qual ele pertence, e outros ainda vindos de teorias científicas, psicológicas, linguísticas, etc. Nessa perspectiva, os conhecimentos constituiriam um subconjunto das crenças dos professores, caracterizado pelo fato de que ele reagrupa asserções sustentadas por provas empíricas e por uma argumentação lógica. Essencialmente, os autores desta síntese compartilham o ponto de vista de Kagan (1992): ao utilizarmos a expressão “crenças dos professores", deve-se subentender o termo "conhecimentos".

Para alguns pesquisadores (cf. particularmente CALDERHEAD, 1996), os conhecimentos e as crenças dos professores estão, de alguma maneira, “encapsulados" em suas experiências profissionais, a ponto de serem indissociáveis. Eles se manifestam por meio dos atos de ensino, quer se trate de planejamento de atividade, de interações com os alunos ou de avaliação. São expressos sob a forma de metáforas ${ }^{11}$, de ações ou de palavras. Sua natureza evidencia tanto a imagem mental quanto as ideias ou proposições, implícitas

9 O texto em inglês ao qual fazemos referência é o seguinte: “Teacher belief is a particularly provocative form of personal knowledge that is generally defined as pre- or invervice teachers' implicit assumptions about students, learning, classrooms, and the subject matter to be taught" (KAGAN, 1992, p. 65).

10 Kagan (1992) escreve: "As a domain, teaching is characterized by an almost total absence of truths, unimpeachably 'correct' answers to the most important issues: why students behave as they do, the nature of learning and cognitive growth, the best way to structure a lesson, etc." (p. 73).

${ }_{11}$ As ideias, crenças e conceitos que regram nosso pensamento não são de natureza puramente intelectual. Segundo Lakoff e Johnson (1985), em particular, eles tomam frequentemente a forma de metáfora. Em Les métaphores dans la vie quotidienne (As metáforas na vida cotidiana), ele mostra que não temos consciência de nosso sistema conceitual; esse se exprime especialmente por meio de metáforas, o que o leva a propor a noção de "metáfora conceitual”. A ideia é, portanto, que utilizando ou escolhendo tal metáfora e não outra, um sujeito revela uma parte do sistema conceitual que estrutura seu pensamento. Partindo desse ponto, pesquisadores recorreram a essa técnica para estudar as crenças dos professores, submetendo-os às metáforas ("Quando nascemos somos uma página em branco...”; “A criança é uma bela planta que convém cobrir de cuidados atentos") e perguntando-lhes quais eles privilegiariam. 
ou explícitas, conscientes ou inconscientes, inferidas a partir daquilo que os professores dizem ou fazem, podendo ser precedidas pela frase "Eu acredito que...”, nos casos em que elas são de natureza declarativa. Essas imagens, ideias ou proposições têm supostamente, do ponto de vista do professor que as sustenta, validade ou credibilidade suficiente para orientar suas ações, assim como alguns de seus julgamentos e decisões. De maneira amplamente consensual (cf. especialmente BORKO; SHAVELSON, 1990; CALDERHEAD, 1996; WOOLFOLK HOY; DAVIS; PAPE, 2006), os pesquisadores consideram que os conhecimentos e as crenças dos professores, inevitavelmente modelados por suas experiências pessoais e profissionais, servem como filtros para analisar e gerir as situações de ensino. Assim, por exemplo, o currículo oficial jamais seria compreendido ou implementado tal como ele é escrito; sua influência sobre a prática dos professores seria sempre mediatizada por meio dos filtros constituídos, entre outros, por seus conhecimentos e crenças pedagógicas gerais, disciplinares e pedagógicas de conteúdos, suas experiências pessoais e profissionais, suas representações, assim como suas percepções relativas aos alunos (REMILLARD, 2005). Na sequência, muitos são aqueles que postulam uma influência das crenças sobre as práticas de ensino (BANDURA, 1986; DEWEY, 1933; FENSTERMACHER, 1979; HUBER; ROTH, 1990; KREMER, 1981; MUNBY, 1982, 1983; NISBETT; ROSS, 1980; PAJARES, 1992; ROKEACH, 1976; STAUB; STERN, 2002; STIPEK et al., 2001; TABACHNICK; ZEICHNER, 1984). Essa influência está, entretanto, longe de ser provada de maneira absoluta, o que leva alguns autores (cf. especialmente HANCOCK; GALLARD, 2004; MELLADO, 1998) a duvidar radicalmente da ligação entre crenças e práticas. Notemos, para completar, que resultados entre esses dois extremos foram igualmente evidenciados pela pesquisa: as crenças e os conhecimentos dos professores estabeleceriam uma ligação condicional com suas práticas (BAUMERT; KUNTER, 2006; CALDERHEAD, 1996; DIEDRICH; THUSSBAS; KLIEME, 2002; KLIEME; REUSSER, 2003; LEUCHTER, 2009; LEUCHTER et al., 2008; LIPOWSKY, 2006; OPDENAKKER; VAN DAMME, 2006).

Embora importante, a questão da ligação entre as crenças e as práticas de ensino não está no centro desta síntese. Seu objeto principal se refere aos tipos de crenças e conhecimentos dos professores, sua organização, assim como seu desenvolvimento por meio da formação inicial e continuada dos docentes, do mesmo modo que ao longo de sua carreira profissional. 


\section{CATEGORIAS DE CRENÇAS E DE CONHECIMENTOS DOS PROFESSORES}

A literatura da área distingue vários tipos de conhecimentos ou de crenças (CALDERHEAD, 1996; LEUCHTER, 2009; SHULMAN, 1987; WOOLFOLK HOY; DAVIS; PAPE, 2006). Devemos a primeira tipologia à Shulman $(1987)^{12}$, que distingue sete tipos de conhecimento:

- conhecimentos disciplinares, que correspondem aos saberes que os professores possuem da matéria que ensinam;

- - conhecimentos pedagógicos gerais, que incluem os princípios e estratégias de gestão do grupo e de organização, especialmente das interações, que transcendem as matérias escolares;

- - conhecimentos curriculares, com ênfase particular no material, nos manuais escolares e no programa que servem de base para o ensino;

- - conhecimentos pedagógicos do conteúdo, que são um amálgama, específico a cada professor, articulando conhecimentos pedagógicos e disciplinares; trata-se, por exemplo, do saber que o professor do curso primário construiu sobre a maneira de ensinar as frações a alunos de 10 anos;

- - conhecimentos relativos aos aprendizes e às suas características, que remetem, por um lado, aos saberes sobre os alunos em geral e, por outro, a alunos específicos de uma turma. A psicologia da aprendizagem e do desenvolvimento é elemento central desses conhecimentos;

- - conhecimentos relativos ao contexto educativo, ao sistema escolar e à sociedade;

- - conhecimentos relativos às finalidades da educação, seus objetivos, valores e bases filosóficas e históricas.

A arquitetura simplificada de Borko e Putnam (1996) reformula os setes tipos inicialmente propostos por Shulman (1987) em uma tipologia feita de três conjuntos ${ }^{13}$ :

- - crenças e conhecimentos pedagógicos gerais: são os saberes e concepções do professor, relativos ao ensino, à aprendizagem e aos

Uma tradução deste texto foi publicada no número 2 do volume 4 da Cadernos Cenpec (SHULMAN, L. Conhecimento e ensino: fundamentos para a nova reforma, Cadernos Cenpec, São Paulo, v. 4, n. 2, p. 196-229, dez. 2014. Disponível em: 〈http://cadernos. cenpec.org.br/cadernos/index.php/cadernos/article/view/293/297>. Acesso em: 12 jan. 2017).

13 É importante notar que nosso texto considera igualmente os ajustes (menores) fornecidos por diversas publicações recentes. 
aprendizes, que transcendem as disciplinas escolares. Eles integram os conhecimentos e as crenças dos professores referentes à gestão da sala de aula (como fazer o conjunto do grupo trabalhar e manter seu envolvimento nas atividades), às estratégias instrucionais (como gerir uma aula, como criar, planejar e estruturar meios educativos, quais estratégias ou rotinas pedagógicas ou interacionais utilizar dentre o repertório profissional, etc.), assim como aos aprendizes, à sua aprendizagem e à sua maneira de lhes ensinar (como os alunos pensam e assimilam a matéria, como o professor pode contribuir para essa aprendizagem). A pesquisa mostra que esses conhecimentos e crenças relativos aos alunos, que ocupam boa parte do repertório cognitivo dos professores, são de grande importância em seu agir eficaz (MARLAND, 1993; MAYER; MARLAND, 1997). Esse tipo de conhecimentos ou crenças engloba igualmente os elementos cognitivos que remetem aos programas, ao sistema educativo, à sociedade, etc.; - crenças e conhecimentos disciplinares: as concepções e os saberes dos professores sobre uma matéria específica. Eles agrupam os conhecimentos e as crenças referentes aos fatos, aos conceitos e à terminologia de uma disciplina em particular, assim como suas ideias organizadoras, as conexões entre essas ideias, as reflexões e os argumentos que as fundamentam, seu desenvolvimento, etc.;

- - crenças e conhecimentos pedagógicos do conteúdo: a tradução dos conhecimentos e das crenças disciplinares mediatizada pelos conhecimentos e crenças pedagógicas gerais para favorecer o ensino. Englobam os saberes e as concepções sobre as maneiras de apresentar e de formular a matéria disciplinar para torná-la compreensível aos outros, assim como uma compreensão daquilo que torna complexa ou simples a aprendizagem de alguns de seus elementos.

Inspirando-se no modelo ecológico de Bronfenbrenner (1986), Woolfolk Hoy, Davis e Pape (2006) propõem um modelo em forma de bonecas russas. No nível mais amplo, eles distinguem as crenças e os conhecimentos dos professores tendo em conta a infância ou a adolescência e o sentido que essas fases atribuem à diversidade dos indivíduos. Em um segundo nível, incluído no anterior, há as crenças e os conhecimentos dos professores sobre o contexto político da educação (as reformas, os padrões, as ideias de responsabilidade e as políticas de gestão, etc.). No nível seguinte estariam as crenças e os conhecimentos sobre o contexto imediato da classe: as características dos alunos (especialmente o gênero, a classe social, etc.), o conteúdo de ensino, etc. Enfim, no centro do modelo, Woolfolk Hoy, Davis e Pape (2006) situam 
aquilo que se relaciona com a identidade profissional e com o sentimento de eficácia. Essa última camada de crenças e conhecimentos seria crucial para a adaptação dos professores às situações instáveis e frequentemente conflituosas que eles devem gerir.

\section{MULTIDIMENSIONALIDADE E MULTIFUNCIONALIDADE DAS CRENÇAS}

Como mencionado, os debates atuais na literatura anglo-saxã se afastam das discussões conceituais que opõem crenças e conhecimentos, preferindo um vocabulário agregador: teachers' beliefs and knowledge para uns (cf. especialmente WOOLFOLK HOY; DAVIS; PAPE, 2006) ou teachers' capacity para outros (GRANT, 2008; GRANT; AGOSTO, 2008; HOWARD; ALEMAN, 2008; MCDIARMID; CLEVENGER-BRIGHT, 2008), indicando desse modo o caráter heterogêneo das estruturas mentais mobilizadas pelos professores. Sob terminologias diferentes ${ }^{14}$, os pesquisadores convergem em direção à ideia de que as investigações futuras devem visar à compreensão profunda do funcionamento das crenças e dos conhecimentos dos professores sobre a ligação entre as crenças e os conhecimentos disciplinares e os conhecimentos pedagógicos do conteúdo, sobre sua utilização flexível na ação, sendo que uma mesma crença pode, como observam Richardson e Placier (2001), se traduzir em diferentes ações, de acordo com a situação e o tipo de aluno.

Leuchter (2009) estima que os conhecimentos e as crenças dos professores são submetidos continuamente a uma pressão temporal e a situações problemáticas complexas. Utilizando as contribuições de pesquisas sobre o saber especializado dos professores, ela propõe caracterizar suas crenças e conhecimentos posicionando-os sobre quatro contínuos, que vão do sistemático ao situado, do explícito ao implícito, do declarativo ao processual, e do cientificamente fundado aos elementos embasados na experiência pessoal e profissional. Ainda segundo a conceitualização da pesquisadora uma contribuição a que retornaremos na discussão -, o agir profissional dos professores engloba conhecimentos e crenças em rede que navegam, de certo modo, no espaço definido por essas quatro dimensões. Essas combinações de crenças e conhecimentos determinam, juntamente com outros fatores ligados ao contexto, aos alunos e à situação pedagógica, a conduta de

14 De nossa parte, continuamos fiéis à expressão teachers' beliefs and knowledge; a expressão teachers' capacity não nos parece esclarecedora. Além disso, a tradução francesa de "capacidade(s) dos professores" nos parece particularmente equivocada. $\mathrm{Na}$ verdade, bebendo na fonte da teoria piagetiana, estaríamos prontos a nos deixar tentar pelo retorno do conceito de esquema. 
ensino do professor e seus processos relativos de pensamentos (LEUCHTER, 2009; WANLIN; CRAHAY, 2012; WANLIN; LAFONTAINE; CRAHAY, submetido para publicação). Assim, os conhecimentos sistemáticos se transformariam progressivamente sob o efeito da experiência profissional, para se adaptarem melhor à ação e à reflexão pedagógica. Resumindo, as crenças dos professores alimentam o agir e a reflexão profissionais e deles se alimentam. Constituindo-se a partir das experiências vividas e das informações, saberes, modelos de pensamento recebidos e transmitidos pela tradição, educação e comunicação social, as crenças ou representações teriam uma visão prática de organização, de domínio do meio e de orientação das condutas. Participando da construção de uma realidade comum a um dado conjunto social ou cultural, elas ofereceriam uma visão funcional do mundo que permite ao indivíduo ou ao grupo dar um sentido às suas condutas, compreender a realidade por meio de seu próprio sistema de referência, portanto, adaptar-se a ela e nela definir um lugar para si. Nessa perspectiva, convém considerar que os conhecimentos, concepções, crenças ou representações ${ }^{15}$ podem preencher funções plurais e, mais particularmente, segundo a análise de Abric (1994), funções de saber, de identidade, de orientação e de justificação. Retomamos essa análise adaptando-a.

A primeira função das crenças consiste em buscar dar sentido às experiências vividas. Para compreender e explicar as realidades às quais os indivíduos se confrontam em sua vida cotidiana, eles recorrem a ideias de origem e de status diversos. Há, portanto, uma preocupação de compreensão, uma tentativa de dar sentido às ações cumpridas e àquelas a realizar. Para Kagan (1992), confrontados às incertezas e ambiguidades inerentes ao mundo escolar e à vida em sala de aula ${ }^{16}$, os professores se esforçam para conferir segurança à sua ação aplicando uma pedagogia pessoal, mais ou menos coerente. Essa busca de sentido pode conduzir a aquisições de conhecimentos, à elaboração de novas crenças ou ao ajuste de antigas convicções e, eventualmente, à remodelagem radical do sistema de crenças do indivíduo. Falaremos de função epistêmica das crenças, referindo-nos à sua mobilização no processo de compreensão executado pelos indivíduos (e, em particular, os professores),

15 O leitor entenderá que nossa análise nos conduz a considerar esses quatro termos, senão como sinônimos, ao menos como intimamente relacionados.

16 Desse modo, esse autor retoma o termo schizophrenic tasks (LIEBERMAN, 1992) para designar as duplas coerções que pesam sobre os professores. Esses têm de diferenciar o ensino mantendo o controle sobre o conjunto da classe; e considerar os interesses individuais atingindo ao mesmo tempo com todos uma base comum de competências. Essas tarefas "esquizofrênicas" colocam os professores em situação de dilema quase permanente (WANLIN; CRAHAY, 2012). 
mas também em referência ao papel de matriz que elas supostamente devem ocupar na seleção e aquisição de novos conhecimentos. Muitos são os autores que atribuem essa função às crenças dos professores (CALDERHEAD; ROBSON, 1991; CLARK; PETERSON, 1986; GRANT, 2008; GRANT; AGOSTO, 2008; HOWARD; ALEMAN, 2008; KAGAN, 1992; PAJARES, 1992; BORKO; PUTNAM, 1996; RICHARDSON, 1996; RICHARDSON; PLACIER, 2001; SCHOMMER, 1990; MCDIARMID; CLEVENGER-BRIGHT, 2008; WOOLFOLK HOY; DAVIS; PAPE, 2006). Em outras palavras, as crenças ofereceriam aos indivíduos um quadro de compreensão dos acontecimentos que permite integrar elementos novos em coerência com seu funcionamento cognitivo e com os valores aos quais eles aderem. No plano coletivo, as crenças ou representações definiriam um quadro de referência comum a um grupo social ou profissional que possibilita um compartilhamento de ideias e de afetos, o que favorece a comunicação interna do grupo e reforça a coesão.

A segunda função é identitária: o compartilhamento de crenças comuns permite aos indivíduos ou grupos de indivíduos se situar no campo social. Em compatibilidade com sistemas de normas e de valores social e historicamente determinados, elas permitiriam a construção de uma determinada identidade social e pessoal (ABRIC, 1994; MUGNY; CARUGATI, 1985). As crenças ou representações são, portanto, concebidas como construções cognitivas que permitem aos grupos sociais atribuir a si uma identidade específica ${ }^{17}$. Compartilhando as mesmas ideias sobre um dado objeto social, um grupo social se constitui e se destaca, por esse próprio fato, de outro grupo. Em alguns casos, defender uma crença (às vezes contra tudo e contra todos) é defender a identidade e a filiação a um grupo social.

As representações, ou crenças, dos professores preenchem uma função que podemos qualificar como normativa na medida em que, algumas vezes, desempenha um papel de orientação, de guia de comportamentos, de ações e de práticas. Frequentemente posta em evidência nos discursos psicopedagógicos, essa função supõe que atribuamos um valor prescritivo às crenças. Isso é plausível em virtude de seu caráter socialmente compartilhado: traduzindo o que é legítimo pensar sobre um dado objeto no interior de seu grupo social de pertencimento, a crença definiria o que é lícito, tolerável ou inaceitável como comportamento ou prática em dado contexto social. Além disso, as crenças operam - a exemplo de todo conhecimento anterior - como esquema cognitivo, que desempenha um papel ativo na seleção e filtragem

Relembremos a esse respeito a distinção de Rozenholtz (1989) entre escolas de baixa unanimidade e de alta unanimidade. 
de informações, assim como na interpretação de situações visando a tornar essa realidade conforme a crença.

Enfim, a quarta função possível das representações ou das crenças é justificadora ou autodefensiva (ABRIC, 1994). Assim, alguns comportamentos são explicados ou justificados do ponto de vista das representações que presidiram suas manifestações (AVIGDOR, 1953; DOISE, 1973; WILSON; KATAYANI, 1968). Como discutiremos mais à frente, pesquisas mostraram que, para jovens professores, o ingresso na função é frequentemente fonte de dificuldades, a ponto de a maior parte deles conhecer um choque de realidade (ver NAULT, 1999; TARDIF; LESSARD, 1999; VEENMAN, 1984). Confrontados com a distância entre a profissão sonhada ou imaginada e a profissão real (NAULT, 1999), os docentes desenvolvem um discurso autodefensivo no qual determinadas crenças podem ser mobilizadas para fins de justificação.

\section{AS CRENÇAS E CONHECIMENTOS DOS PROFESSORES PODEM EVOLUIR?}

\section{Colocando em perspectiva}

A questão da "maleabilidade" das crenças e conhecimentos dos professores é crucial na perspectiva de sua formação. Podemos considerar, de fato, que os dispositivos de formação inicial, mas também os dispositivos de "reciclagem" ou de formação continuada dos professores estão fundados sobre um postulado de maleabilidade. Fundamentalmente, o principal pressuposto de um bom número de dispositivos de formação é o seguinte: transformando as crenças (e/ou concepções) dos professores, melhorando seus conhecimentos disciplinares e pedagógicos (correspondentes ao mesmo tempo às crenças e conhecimentos pedagógicos gerais e às crenças e conhecimentos pedagógicos do conteúdo), melhoramos suas práticas ${ }^{18}$. Esse pressuposto pode ser decomposto em duas proposições:

- as crenças dos professores determinam suas práticas;

- as crenças dos professores são modificáveis ou, em outras palavras, elas podem evoluir.

No âmbito desta síntese, interessamo-nos principalmente pelo exame das pesquisas que tratam da segunda proposição, deixando para mais adiante

18 Assim Kagan (1992) escreve: "We cannot expect any program of inservice teacher education to effect change in teachers' behaviors without also effecting change in their personal beliefs" (p. 77). Em outro lugar, no mesmo texto, ela diz a mesma coisa no que se refere a preservice teacher education. 
o exame sistemático das relações (complexas) entre crenças e práticas. Será necessário, entretanto, abordar a questão importante da prioridade da mudança das crenças em relação às práticas.

Que as crenças e os conhecimentos dos professores sejam modificáveis é uma afirmação bem controversa na literatura de pesquisa em educação. Um primeiro exame dos estudos empíricos dá a impressão de que há tanto resultados que estabelecem uma resposta negativa quanto dados que autorizam uma posição otimista. Em artigo de 1998, intitulado "How teachers change", Richardson destaca que a afirmação "Professores não mudam, resistem à mudança" coabita, na literatura, com a afirmação contraditória "Professores mudam o tempo todo". Mais precisamente, ela observa que autores como Duffy e Roehler (1986) ou Fullan (1991) afirmam, com base em suas pesquisas, que os professores são resistentes às mudanças. 0 trabalho histórico de Cuban (1984; ver também CUBAN, 1988) muito contribuiu para a ideia de uma persistência quase imutável de formas de ensino; ele fala sobre uma continuidade obstinada da forma de instrução tradicional, resistente às múltiplas tentativas de reforma pedagógica que se esforçaram para introduzir o plano Dalton, a pedagogia de projetos, o trabalho em equipe, a classe aberta, etc. Essa análise foi retomada por Gage (1986), que tira dela o argumento para concluir sobre o "caráter inexpugnável dessa fortaleza que é o ensino tradicional” (p. 420). Ao contrário, em artigo intitulado "Significant and worthwhile change in teaching practice", Richardson (1990) observa, em diversos professores, modificações em suas maneiras de ensinar, que vão de pequenas mudanças a transformações radicais; uma constatação que ela reitera em estudo subsequente (RICHARDSON, 1994).

Dois esclarecimentos conceituais se impõem neste momento. Convêm distinguir, por um lado, mudança de crenças e mudança de práticas e, por outro, modificações de superfície (first order change na literatura anglosaxã) e transformações em profundidade (second order change ou structural changes ${ }^{19}$ ). Em uma síntese intitulada "Research on teacher education" e publicada na terceira edição do Handbook of research on teaching, Lanier e Little (1986) concluem que mudar o comportamento e os pensamentos dos professores é possível. Contudo, é importante situar essa conclusão em seu contexto histórico. Encontramo-nos, no momento da publicação desse Handbook, no apogeu das pesquisas processo-produto, e a síntese elaborada por Lanier e Little trata principalmente das modificações de procedimentos de ensino, portanto modificações de primeira ordem ou de

19 Sobre essa distinção, ver especialmente Cuban (1988). 
mudanças de superfície. Ora, para Richardson e Placier (2001), ninguém duvida da capacidade dos professores de modificar uma ou outra estratégia comportamental específica (cf. p. 915). De nossa parte, essa tomada de posição parece subestimar a dificuldade das mudanças comportamentais, uma questão que um de nós tratou outrora em uma síntese intitulada ${ }^{20}$ "Contraintes de situation et interactions maître/élèves: changer sa façon d'enseigner, est-ce possible?" 21 (CRAHAY, 1989). Entretanto, concordamos com Richardson e Placier quando consideram que a questão da mudança das crenças é posta doravante em um contexto paradigmático diferente daquele marcado pelo comportamentalismo dos anos 1970 e 1980.

Shulman (1987) e Fenstermacher $(1979,1986)$ foram dois dos principais artesãos dessa mudança inscrita na passagem da era behaviorista para o período ainda atual, dominado pelo cognitivismo. Essa mudança paradigmática remonta precisamente a 1974, data na qual o Painel 6 do National Institute of Education (NIE), presidido por Shulman, publica um relatório intitulado "Teaching as clinical information processing”. Esse relatório insiste na necessidade de realizar pesquisas com o objetivo de compreender a vida mental dos professores, apreender os processos cognitivos que eles mobilizam para enfrentar um meio complexo, que Doyle $(1975,1977,1979$, 1986) caracteriza pela multidimensionalidade, simultaneidade, urgência e imprevisibilidade. A influência do Painel 6 na pesquisa sobre o ensino foi considerável. Atribuímos-lhe o declínio das pesquisas processo-produto e o advento da corrente batizada de "pensamento do professor", da qual Shulman (1987) criticará as lacunas ressaltando que as pesquisas realizadas nessa perspectiva entre 1975 e 1985 ignoram o conteúdo ensinado (para uma síntese dessa corrente, ver CLARK; PETERSON, 1986, ou BORKO; SHAVELSON, 1990). Como indicado por Shulman, a compreensão do processo de ensino não pode ignorar as diversas espécies de conhecimentos ativados pelos professores para conduzir a sala de aula e tentar suscitar a aprendizagem dos alunos.

A todas essas mudanças teóricas, acrescente-se a influência da reflexão filosófica de Fenstermacher (1979, 1983, 1984a, 1984b, 1985, 1986). Essa trata principalmente do uso que podemos fazer das pesquisas empíricas para pensar a formação dos professores. Antecipando as críticas dirigidas

20 Encontraremos também, nessa antiga síntese, a distinção entre dois níveis de mudança (de superfície e em profundidade) e, na sequência, uma tipologia de mudanças viáveis no que diz respeito ao ensino.

${ }_{21}$ "Restrições de situação e interações professor/aluno: mudar sua forma de ensinar é possível?" (N. de T.) 
atualmente à educação baseada em evidências (SAUSSEZ; LESSARD, 2009), esse pensador da educação se insurge contra um aplicacionismo estrito que, na prática, restringe os professores a se conformar com as recomendações tiradas dos resultados de pesquisas e os transforma em executores, até mesmo em "pequenos soldados", obrigados a obedecer aos padrões de qualidade definidos em termos das melhores práticas. Para Fenstermacher, o professor deve ser um profissional que sabe por que age de tal maneira e não de outra. Em outras palavras, a qualidade, o fundamento e a coerência dos argumentos e/ou das justificativas que sustentam a escolha de uma prática são tão importantes quanto os supostos efeitos dessa prática. 0 título de seu artigo de 1985 é, a esse respeito, instrutivo: "Who decides the worth of educational research?” (“Quem decide o valor da pesquisa educacional?”), uma questão que ele completa por outra, repetida na maioria de seus textos: os resultados de pesquisas sobre o ensino podem ditar por si só os programas de formação de professores e aquilo que se deve considerar como o bom ensino? Essa reflexão subjaz a todos os trabalhos empíricos que se propõem a apreender em que medida as crenças e os conhecimentos dos professores são modificáveis e/ou se transformam em profundidade.

Richardson e Placier (2001) têm o mérito de situar sua revisão das pesquisas sobre o tema nesse contexto paradigmático. Do nosso ponto de vista, essa revisão de síntese é ainda pertinente, quase dez anos depois, quaisquer que sejam as contribuições subsequentes (EVERTSON; WEINSTEIN, 2006; MUNBY; RUSSELL; MARTIN, 2001; WOOLFOLK HOY; DAVIS; PAPE, 2006). Tem ainda outro mérito: as autoras agrupam o conjunto das pesquisas em duas categorias principais: mudanças individuais e de pequenos grupos, de um lado, e desenvolvimento da equipe de outro, as quais apresentam subcategorias (três para o primeiro grupo e duas para o segundo). De nossa parte, propomos uma estrutura em três categorias:

- - as pesquisas que tratam de mudanças naturais, qualificadas também como voluntárias (voluntary and naturalistic changes) ${ }^{22}$, às quais acrescentamos aquelas que abordam os estágios de desenvolvimento que pontuam - é o postulado - a carreira dos professores;

- - os estudos que se propõem a medir os efeitos dos programas de formação dos professores, que, na maioria, dizem respeito à formação inicial;

22 O termo voluntary tem uma acepção que se situa entre intencional evoluntário. Richardson e Placier (2001) designam aí, na verdade, as mudanças que não são impulsionadas deliberadamente do exterior como são aquelas que resultam de um dispositivo de formação. 
- as pesquisas que evidenciam a corrente nomeada desenvolvimento da equipe (staff development) ${ }^{23}$.

Ademais, introduziremos uma seção que abordará as crenças dos professores iniciantes, logo após a seção que trata das fases de desenvolvimento; as pesquisas realizadas sobre esse tema permitem compreender melhor os estudos que avaliam os efeitos dos programas de formação.

Queiram ou não, os professores mudam ao longo da carreira

Essa é a principal conclusão que é possível tirar dos trabalhos baseados nas narrativas de vida dos professores (estudos biográficos), assim como de numerosos estudos que tentaram identificar os estágios de desenvolvimento da carreira docente.

Entre os estudos biográficos mencionaremos o de Butt, Raymond, McCue e Yamagisi (1992), o de Bullough e Baughman (1997) e o de Russell (1995); para um recenseamento mais completo, ver Richardson e Placier (2001). No primeiro, os pesquisadores apresentam dois estudos de caso. Os dois professores foram convidados e aceitaram fornecer uma descrição de seus contextos de trabalho, de suas práticas pedagógicas (especialmente a sua maneira de pôr em prática o currículo), assim como de sua reflexão retrospectiva sobre sua vida pessoal e profissional. No que diz respeito a essa reflexão, foi-lhes pedido para fazer uma relação entre suas experiências passadas e a atual. Butt, Raymond, McCue e Yamagisi (1992) evidenciam uma evolução dos dois professores influenciada, segundo suas palavras, por uma diversidade de eventos ligados aos alunos, aos colegas, aos pais e mesmo à sua vida pessoal. Bullough e Baughman (1997) chegam à mesma conclusão em seu estudo colaborativo de oito anos, iniciado no momento em que Kerrie (Baughman) entra em ação. Para os dois autores é certo que mudanças foram operadas na cabeça de Kerrie, em suas crenças e em sua identidade profissional (apreendidas pela análise das metáforas que ela utiliza para se definir e para descrever sua prática), e que essas mudanças são indissociáveis de sua evolução pessoal. Em outras palavras, desenvolvimento pessoal e desenvolvimento profissional seriam indissociáveis. Quanto a Russell (1995), formador de professores, ele voltou a ensinar física durante dois anos em uma escola de ensino médio e realizou um autoestudo que o levou a concluir acerca da importância da experiência prática no desenvolvimento profissional. Essa ideia é cara a Russell (1994), que a compartilha com seu colega Munby (cf.

23 Na síntese de Richardson e Placier (2001), as duas primeiras categorias evidenciam aquilo que os pesquisadores nomeiam "individual and small group changes". 
em particular MUNBY; RUSSELL, 1994, texto no qual os autores desenvolvem o conceito de autoridade da experiência); ela é novamente expressa em um artigo de 1998 (MUNBY, CUNNINGHAM; CHIN, 1998).

O que dizer dessas pesquisas? A constatação de que os professores evoluem no plano profissional não nos parece contestável. As pesquisas que contrastam os experts e os noviços ou os professores experientes e os professores iniciantes (cf. especialmente o estudo de RUSSELL et al., 1988) o mostram abundantemente. Há, portanto, uma espécie de evidência. Quais são os fatores que contribuem para essa evolução? Essa é a questão importante. Os estudos de Russell (1988) e de Bullough e Baughman (1997) nos parecem tão excepcionais que julgamos difícil poder generalizar as suas constatações. A título de argumento, observamos que, no prefácio do livro de Bullough e Baughman (1997), Berliner destaca que Kerrie é o tipo de professora que todos os pais sonham para seus filhos. Quanto à Russell (1998), ele decide retomar o trabalho para pôr à prova suas concepções de formador de professores diante da realidade; a abordagem é admirável, o que não the confere a anulação de seu certificado de validade científica. Notemos, ademais, que outros pesquisadores observam uma permanência da maneira de ensinar de diversos indivíduos. Richardson e Placier (2001) citam sobre isso o estudo de caso de Louden (1991), assim como o trabalho de Zahorik (1990), que agrupa quatro estudos de caso. No final, podemos chegar à conclusão de que há, ao mesmo tempo, uma mistura de estabilidade e de variabilidade no desenvolvimento profissional dos professores. Que facetas restam constantes e quais evoluem? No estágio atual das pesquisas, não é possível responder a essa questão, tal a importância que parece ter a idiossincrasia dos professores. Essa característica é destacada por vários pesquisadores. Richardson e Placier (2001) mencionam sobre o assunto os estudos de Ball e Goodson (1985) e de Munby e Russell (1992). É preciso fazer uma menção específica ao estudo de Ashton (1984), que observa que os professores caracterizados por uma alta percepção de suas competências são mais propensos a mudar suas práticas que os outros. Enfim, novamente, segundo Richardson e Placier (2001), pesquisadores propuseram tipologias de professores em função de seu comprometimento com a profissão (MARKS; GERSTEN, 1998) ou em função de sua atitude em face da introdução de um novo currículo (LINDBAD, 1990). Encontramos igualmente categorizações análogas nas pesquisas francófonas (CRAHAY; DONNAY, 2001).

A ideia de uma evolução natural (e quase inevitável) dos professores ao longo da carreira é encontrada em pesquisas que buscam identificar os estágios 
de desenvolvimento que demarcam essa evolução. Aqui, em oposição aos estudos anteriormente citados, postulamos que todos os professores evoluem atravessando as mesmas etapas. É, claramente, o caso do estudo clássico de Fuller (1969), retomado e prolongado por seu trabalho com Bown (FULLER; BOWN, 1975), que distingue quatro fases: uma fase de formação, caracterizada por muito idealismo; uma fase de sobrevivência, que corresponde à entrada em função e marcada por um choque de realidade, do qual os efeitos são devastadores em relação aos ideais iniciais; uma fase focada nas práticas e situações de ensino e, enfim, uma fase terminal, em que os professores manifestam preocupações centradas nos alunos, suas aprendizagens e seu desenvolvimento ${ }^{24}$. Mais recentemente, Nias (1989) encontrou, em um estudo realizado junto a 99 professores, aproximadamente as mesmas etapas identificadas por Fuller. Na mesma linha, podemos ainda encontrar dois estudos. A partir de pesquisa realizada sobre 50 professores, Mevarech (1995) distingue cinco fases no desenvolvimento profissional que vão de uma etapa de sobrevivência a uma etapa de implementação planejada do currículo, essa última vinculada a manifestações de mudanças conceituais. Feiman-Nemser (1983) identifica quatro fases (pretraining, preservice, induction e inservice). Mencionemos ainda o trabalho de Berliner (1994), que distingue cinco níveis de expertise (noviço, iniciante avançado, competente, competente avançado - ou proficient - e, enfim, expert).

Sintetizando os estudos sobre a socialização profissional dos professores, Nault (1999) propõe um modelo em cinco fases. Haveria, inicialmente, a fase da profissão sonhada ou imaginada, que precede a entrada na formação inicial e no decorrer da qual o adolescente constrói para si uma imagem daquilo que ele quer se tornar e forja um projeto profissional. Durante a segunda fase, a da formação inicial, o futuro professor adquire os saberes, o saber-fazer (savoirfaire) e o saber-ser (savoir-être) de sua futura profissão. Paralelamente, ele é submetido à influência de forças externas que visam a modelar seu "eu profissional” à luz das teorias pedagógicas. Em seguida, viria a fase de inserção profissional. De importância capital para o futuro dos professores, ela pode ser decomposta em três etapas: primeiro a etapa da euforia antecipadora; depois a etapa do "choque de realidade" e, enfim, a etapa da consolidação dos conhecimentos, durante a qual, à medida que obtém sucesso, o novo 24 Originalmente, Fuller (1969) distinguia três fases de desenvolvimento: "a fase a-pedagógica", "a fase autocentrada e centrada sobre a matéria" e "a fase allo-centrada sobre os alunos". No texto, retomamos o que é mais frequentemente mencionado na literatura subsequente e que inspira a publicação de 1975 (FULLER; BOWN, 1975). Essa terminologia remete, ao menos em parte, aos trabalhos de Bullough (1987) e de Ryan (1986). 
professor constrói estruturas permanentes de funcionamento e de reflexão. A quarta fase corresponderia a uma socialização mais personalizada. No interior da sala de aula, o professor continua a se desenvolver profissionalmente em razão das experiências, de suas tentativas e erros. A derradeira fase é chamada fase de socialização radiante, pois, após ter superado com sucesso situações complexas, o professor é levado a compartilhar sua expertise com os colegas. Ele está no topo de sua arte.

Em todas essas pesquisas, evolução é sinônimo de desenvolvimento e, assim, de progresso, até mesmo de crescimento profissional. Isso é particularmente evidente na síntese que propõe Nault (1999) dessa literatura. Lendo a sucessão de fases, não podemos deixar de pensar que se trata mais da projeção de um ideal do que da descrição de etapas de desenvolvimento. No final de uma evolução, às vezes longa e semeada de obstáculos que ele supera, o professor atingirá um ponto ômega, o da expertise. Além disso, encorajado por um ideal de solidariedade, ele irradia e dispensa seu saber profissional a seus colegas. Podemos, evidentemente, sonhar que seja assim, mas é preciso recear que nem todos os professores atinjam esse último estágio de crescimento. Os trabalhos sobre a depressão e o esgotamento (burn out) dos professores estão aí para nos trazer à realidade. Única exceção a essa tendência de adoçar a realidade é o estudo de tipo retrospectivo realizado por Huberman, Grownver e Martin (1989) sobre 160 professores suíços do ensino secundário, convidados a traçar, ao longo de entrevistas semiestruturadas, seus percursos profissionais. Para eles, o último estágio é o do descomprometimento. Para além disso, Huberman e colaboradores destacam que todos os professores não passam pelos seis estágios que ele pôde identificar, considerando que a sua evolução se inscreve em contextos e em histórias de vida profissional marcados pelo aparecimento e às vezes desaparecimento de diversas reformas, sendo que esses acontecimentos afetam necessariamente seu futuro.

Sem dúvida, devemos reter dessas pesquisas que os professores evoluem. Em contrapartida, é pouco provável que todos atravessem as mesmas etapas de desenvolvimento, como é duvidoso que todas as carreiras de professores alcancem uma apoteose. 0 modelo piagetiano de desenvolvimento linear é agora abandonado na psicologia do desenvolvimento e substituído por uma concepção de ondas que se sobrepõem. Segundo essa metáfora de Siegler (1999), a cada fase de desenvolvimento, em cada subdomínio, a criança dispõe de várias estratégias cognitivas que, à semelhança das ondas que se aproximam da praia por um vaivém progressivo, são susceptíveis de se 
suceder rapidamente, mas também de se sobrepor e, portanto, de entrar em competição. Com a experiência, e segundo as situações, a criança aprende a escolher uma ou outra maneira de proceder. Podemos supor que esse modelo geral, evidenciado pela observação das crianças, é válido - ao menos, parcialmente ${ }^{25}$ - para os professores. É o que sugerem os estudos que se esforçaram por identificar etapas no desenvolvimento dos professores confrontados com as inovações curriculares. Assim, em um estudo de Schifter (1995), professores atravessam quatro etapas para se apropriar de um currículo construtivista de matemática, ao longo das quais suas concepções do ensino de matemática se transformam. Eles passam de uma concepção que atrela a disciplina a uma acumulação de fatos para uma concepção em que a investigação sistemática desempenha um papel central. Do mesmo modo, Hollingsworth (1989), observando como estudantes em formação se apropriam do ensino de leitura, constata que eles devem dominar as técnicas de manejo da sala de aula antes de poder trabalhar suas crenças pedagógicas e, particularmente, as crenças pedagógicas sobre o conteúdo. Resumindo, com essas pesquisas temos a prova de que, em certas circunstâncias, as crenças dos professores podem evoluir.

Retemos ainda dos estudos que tratam dos estágios de desenvolvimento, a noção de choque de realidade (cf., para uma síntese, VEENMAN, 1984, mas também TARDIFF; LESSARD, 1999), o que significa que, para a maior parte dos professores iniciantes, a inserção profissional assemelha-se a um desencantamento brutal, no decorrer do qual lhes é necessário renunciar às "belas ideias" e às crenças que tiveram no fim de sua formação inicial, ou antes mesmo de concluí-la. É, na verdade, o que tendem a indicar os estudos realizados sobre as crenças dos futuros professores no começo da formação, estudos que passamos a revisar na próxima seção.

As concepções dos futuros professores no início da formação

Segundo várias pesquisas (por exemplo, BOOK; BYERS; FREEMAN, 1983; WEINSTEIN, 1988, 1989; PINES; WEST, 1986), os futuros professores manifestam desde o início da formação uma grande confiança em sua capacidade de ensinar. Segundo Richardson (1996), esse resultado seria flagrante tanto entre as nações quanto através do tempo, ou seja, a partir dos anos 1950 até meados dos anos 1990. Weinstein (1988) trata desse tema como um "otimismo irrealista". Os estudantes subestimariam amplamente

25 Não podemos excluir, por parte dos professores, momentos de depressão e processos de declínio que são menos frequentes de observar no desenvolvimento das competências cognitivas das crianças. 
a complexidade da profissão. Jensen (1998) questiona em que medida esse otimismo é susceptível de levá-los a um investimento mínimo na formação.

Mais recentemente, Montgomery, Legault, Gauthier e Bujold (1999) avaliaram o sentimento de eficácia pessoal de 431 estudantes canadenses por meio de um questionário administrativo durante a primeira semana de formação. Uma parte dos estudantes estava inscrita na graduação (baccalauréat) ${ }^{26}$ que os prepara para atuar como professores dos anos finais da educação básica [ensino secundário], enquanto a outra realizava o curso de formação para atuar nos anos iniciais [ensino primário]. Seus resultados se apresentam na mesma direção daqueles dos estudos precedentes, mas aparece um detalhe: $94,2 \%$ dos participantes estimaram, de modo geral, ser mais competentes do que um professor iniciante. Parece, entretanto, que os resultados relativos às competências sobre as relações com os alunos são muito mais elevados do que as competências que requerem um saber-fazer específico (avaliação das aprendizagens, o manejo da classe, a planificação das atividades, a intervenção junto aos alunos mais "difíceis" e a análise das práticas pedagógicas). Os autores do estudo estimam que tal sentimento geral de confiança "pode ser a garantia de atitudes positivas e de estratégias proativas eficazes assim que surgem problemas inerentes à tarefa" (MONTGOMERY et al., 1999, p. 161), mas que, levado ao extremo, "pode ser semelhante a um pensamento mágico, ou seja, à convicção de que eles serão poupados dos problemas que afligem os outros" (p. 161).

Outros estudos sugerem que, no início da formação, os estudantes concebem o ensino-aprendizagem como um processo passivo ou transmissivo. Para eles, ensinar consiste em transmitir fatos e a aprendizagem se dá pela memorização desses fatos (BLACK; AMMON, 1992; BROOKHART; FREEMAN, 1992; CALDERHEAD, 1988; HOLT-REYNOLDS, 1992; MAHLIOS; MAXSON, 1998; MCDIARMID, 1990; RUSSELL, 1988). Sobre o tema, Strauss e colegas (STRAUSS, 1993; STRAUSS; SHILONY, 1994) resumem as concepções dos alunos-mestres em termos de modelos mentais que combinam crenças epistêmicas e concepções pedagógicas do tipo transmissivo. Eles escrevem:

26 Em alguns países francófonos como Canadá e Bélgica, o baccalauréat é equivalente à graduação, enquanto na França esse nome é dado à prova realizada no fim do ensino médio (Lycée) para a obtenção do certificado de conclusão dessa etapa do percurso escolar. (N. de T.) 
Um postulado de base de seus modelos mentais supõe que o conhecimento existe fora da mente das crianças. Ele se situa na mente do professor, nos livros, etc. Em geral, as crianças têm conhecimentos, mas eles são frequentemente incompletos ou incorretos. Às vezes, eles não têm conhecimentos sobre o tema do domínio que estamos ensinando. Essa posição leva a considerar o ensino (e a aprendizagem das crianças que daí decorre) como sendo constituído de duas partes principais. Primeiro, o professor deve encontrar um meio de o conhecimento entrar na mente das crianças. Em segundo lugar, uma vez que esse conhecimento entra em suas mentes, o professor deve agir de tal modo que as crianças vão mudar a nova matéria do lugar em que ela entrou e levá-la ao lugar em que ela vai ser estocada, adicionando-a ao estoque atual de conceitos, competências, etc. já aprendidos (STRAUSS, 1993, p. 154).

Destaquemos ainda estudos relativos às concepções do "bom professor" ou do "bom ensino" que sugerem uma tendência a minimizar os aspectos acadêmicos ou cognitivos e a privilegiar os aspectos interpessoais ou afetivos do ensino (por exemplo, BROOKHART; FREEMAN, 1992; MONTGOMERY et al., 1999). Em um estudo realizado por questionário com 473 candidatos ao magistério (desses, 78\% de mulheres), Book, Byers e Freeman (1983) constatam que, para a maioria deles, o ensino é caracterizado como uma forma de relação parental, tendo por objetivo desenvolver a identidade dos alunos. Claramente, mediante suas respostas, os futuros professores subestimam a faceta "acadêmica" da profissão, assim como os problemas relacionados à gestão do grupo, privilegiando os aspectos psicológicos e a socialização dos alunos. Eles consideram também que ensinar não se aprende; para progredir na profissão, é preciso se alimentar das intuições e das próprias experiências. No que diz respeito às expectativas em relação à preparação e à formação, a maioria dos estudantes atribui importância primordial à aprendizagem na prática e aos estágios profissionais. Eles os consideram como as duas principais fontes de conhecimentos profissionais. Outras fontes do mesmo tipo são designadas na seguinte ordem de importância decrescente: os cursos de psicologia da educação, sua experiência como aluno, as leituras pessoais e os cursos sobre os fundamentos sociofilosóficos da educação. Enfim, confirmando outros estudos do mesmo tipo, grande parte dos estudantes se considera capaz de ensinar e não exprime a necessidade de possuir conhecimentos profissionais para tanto. Esse sentimento elevado de autoconfiança se encontra sem distinção do tipo e da etapa de ensino (préescolar, primário ou secundário) a que os estudantes se dirigem.

As tendências dos estudos sobre as crenças relativas ao ensino e à aprendizagem devem ser consideradas com sensatez. Os futuros professores estão longe de formar um grupo homogêneo. Várias pesquisas concluem pela variedade das concepções dos futuros professores (por 
exemplo, GURNEY, 1995; SCHMIDT; KENNEDY, 1990). Assim, explorando as metáforas de 124 estudantes inscritos no curso de graduação para o ensino primário (baccalauréat) ${ }^{27}$, Leavy, McSorley e Boté (2007) os classificaram principalmente em termos de concepções behavioristas-empiristas, cognitivas-construtivistas e situadas (perspectiva sócio-histórica). No início da formação, eles se distribuem respectivamente nas seguintes proporções, de acordo com as concepções que apresentam: 49\%, 24\% e 18\%. Ademais, ainda que existam aspectos em comum entre os futuros professores do secundário e do primário, vários estudos (citados por JENSEN, 1998) mostram diferenças. Por exemplo, os estudantes que se preparam para o ensino primário teriam uma concepção de ensino mais centrada no aluno, ao passo que aqueles que ensinarão no secundário atribuem mais importância à matéria (BOOK; FREEMAN, 1986).

As crenças dos professores mudam ao longo da formação?

Estudo do efeito dos currículos de formação sobre a evolução das crenças e dos conhecimentos docentes

Richardson (1996) inicialmente, Borko e Putnam (1996) em seguida, e, por fim, Richardson e Placier (2001) fizeram o recenseamento das pesquisas que têm por objetivo estabelecer o efeito dos currículos de formação inicial sobre a evolução das crenças dos futuros professores. Suas conclusões são pessimistas, a ponto de Borko e Putnam (1996) consagrarem uma parte importante da discussão dos resultados aos obstáculos às mudanças. Richardson e Placier (2001) são mais moderados ao falar da dificuldade de desenvolver as crenças dos jovens professores. De nossa parte, indo ao encontro da conclusão de Richardson e Placier (2001), nos parece, sobretudo, que a diversidade de resultados e de métodos de pesquisa nos força a ser prudentes.

Fundamentemos essa posição. Podemos primeiro observar que, se pesquisadores concluem que mudanças são operadas ao longo da formação (por exemplo, HOLLINGSWORTH, 1989; AMMON, 1991; LEVIN; AMMON, 1992; WINITZKY, 1992; JONES; VESILIND, 1996; WINITZKY; KAUFCHAK, 1997), uma maioria de estudos conclui que as crenças são estáveis (por exemplo, ZEICHNER, TABACHNICK; DENSMORE, 1987; FEIMAN-NEMSER, 1990; TICKLE, 1991; WILCOX et al., 1991; MCDIARMID, 1992; MUNRO, 1993; OLSON, 1993; TILEMA; KNOL, 1997; CRAHAY; ORY, 2006; SABAN; KOCBEKER; SABAN, 2007). A título de ilustração da categoria de pesquisas com conclusão negativa,

Equivalente ao curso superior de Pedagogia. (N. de T.) 
mencionaremos, particularmente, o programa de pesquisa $\mathrm{TELT}^{28}$, no qual um número significativo de estudos de caso de professores em formação foi realizado com o objetivo de apreender a evolução de suas crenças no que tange à heterogeneidade dos alunos e aos efeitos das mudanças de crenças sobre o processo de ensino-aprendizagem. Os pesquisadores não notaram nenhuma mudança substancial nas crenças ao longo da formação.

Mais reservados, outros pesquisadores tiram conclusões que assinalam que determinados estudantes evoluem em suas crenças $^{29}$ (BOLIN, 1990; KORTHAGEN, 1988; MARKES, 1995), ao passo que outros assinalam indícios de evolução após uma fase de "resistência" (CIVIL, 1996; HARINGTON; HATHAWAY, 1994). Enfim, é preciso ainda ressaltar os estudos que, medindo diferentes categorias de crenças, observam mudanças em algumas delas e não em outras (KORTHAGEN, 1988; FEIMAN-NEMSER et al., 1989; WOOLFOLK HOY; BURKE SPERO, 2005). É lamentável que a maioria dos estudos esteja concentrada na evolução de um único tipo de mudança, pois podemos levantar a hipótese - retomaremos esse ponto mais à frente - de que certas crenças são mais difíceis de modificar que outras. Ora, se vários estudos, tendo em conta as ideias pedagógicas em vigor ao longo das últimas décadas, abordam o desenvolvimento entre os estudantes de concepções construtivistas de aprendizagem ou de ensino, outros se debruçam sobre o desenvolvimento de um pensamento reflexivo, e outros ainda sobre as crenças que dizem respeito ao ensino de matemática, à repetência ou à educação multicultural. Se cruzarmos essa segunda dimensão com a precedente, que concerne à tendência dos resultados, podemos elaborar o quadro presente no Anexo $1^{30}$.

Destaquemos ainda que a amplitude dos estudos é extremamente variável. Assim, Olson (1993), baseado no estudo de caso de dois estudantes, conclui que os futuros professores não mudam suas crenças sobre a "boa maneira de ensinar" depois dos cursos de formação. Ao contrário, o estudo realizado na Bélgica por Crahay e Ory (2006), sobre as crenças relativas à repetência, trata de 650 alunos-professores. Do mesmo modo, os métodos

${ }_{28}$ Teacher education and learning to teach, programa dirigido pelo Centro de Pesquisa sobre a Formação de Professores da Universidade de Michigan.

29 Notemos que, na maior parte dos estudos que concluem existir uma mudança, os autores afirmam que determinados estudantes mudem suas crenças e/ou que a transformação das crenças se produza em diversos graus segundo os estudantes (RICHARDSON, 1996).

30 Os anexos não foram traduzidos nesta versão do texto. Os originais podem ser consultados na versão eletrônica do artigo na Revista Francesa de Pedagogia. CRAHAY, M.; WANLIN, P.; ISSAIEVA, E; LADURON, I. Fonctions, structuration et évolution des croyances (et connaissances) des enseignants. Revue Française de Pédagogie, n. 172, jul./set. 2010. Disponível em: 〈https://rfp.revues.org/2296〉. Acesso em: 4 jan. 2016. 
utilizados para apreender as crenças também variam: questionário (CRAHAY; ORY, 2006); entrevista (por exemplo, KORTHAGEN, 1988); metáforas, cartas conceituais (por exemplo, JONES; VESILIND, 1996; WINITZKY, 1992; WINITZKY; KAUFCHAK, 1997), dilemas ou situações problemáticas a resolver (por exemplo, KOTHAGEN, 1988; ZEICHNER; TABACHNIK; DENSMORE, 1987), etc. Notemos que a conclusão, a saber, se houve ou não mudança, é sempre uma questão de apreciação. Forneceremos dois exemplos. Saban, Kocbeker e Saban (2007), que analisaram as metáforas relativas ao conceito "professor" expressas por 1.142 futuros docentes, concluem que a hipótese de que os estudantes do último ano escolheriam mais imagens metafóricas centradas sobre o aluno não é confirmada. Todavia, mudanças nas respostas dos estudantes foram constatadas. Entre as seis categorias metafóricas dominantes identificadas na amostra (professor como transmissor de saber, escultor/artesão, cultivador/artesão, conselheiro, “facilitador” e líder cooperativo), duas diferenciam os estudantes que estão entrando nos cursos e os estudantes que os estão concluindo: os primeiros expressam mais imagens voltadas para o desenvolvimento (cultivador/artesão), ao passo que os últimos propõem mais metáforas que ilustram a facilitação.

No contexto belga, Crahay e Ory (2006) realizaram um estudo quantitativo com futuros professores do primário de seis Escolas Superiores de Pedagogia - HEP (Hautes Écoles Pédagogiques) - a fim de avaliar em que medida suas crenças sobre a repetência mudam no decorrer da formação. As informações obtidas mostram que os estudantes de 1 음 ano se declaram claramente a favor da reprovação, particularmente no início da formação, enquanto a opinião de seus colegas do $2^{\circ}$ e do último ano é, em média, mais amenizada. Entretanto, os pesquisadores observam que a evolução desse posicionamento em geral, no que diz respeito à repetência, não se apoia sobre um desenvolvimento das concepções quanto aos efeitos específicos (escolares, cognitivos e sociais) da repetência, nem sobre uma transformação de suas crenças quanto às causas do fracasso escolar. Em especial, em fim de formação como no começo, os futuros professores incriminam os alunos (sua falta de esforço, sua maturidade ou ainda suas baixas aptidões), bem como suas famílias e relutam em questionar o ensino recebido ou mesmo o funcionamento geral da escola. Além disso, eles persistem em negar o peso da influência da origem sociocultural dos alunos na fabricação do fracasso escolar. Por fim, Crahat e Ory (2006) concluem que não houve transformação em profundidade das crenças da maior parte dos professores em formação.

Evidentemente, os autores não se contentam em registrar o fracasso das 
tentativas de transformação das crenças dos professores. Cada um, à sua maneira, tenta uma explicação. Retornaremos a esse ponto, crucial, na discussão.

Estudos relativos ao efeito dos cursos sobre as crenças dos professores em formação

Há estudos que tratam do efeito específico de certos cursos sobre as crenças e conhecimentos dos professores em formação. As conclusões são, aqui também, predominantemente pessimistas. Assim, McDiarmid (1992) observou que as crenças dos estudantes em relação à educação multicultural mudam pouco após uma série de exposições sobre o assunto. Holt-Reynolds (1992) observou que os estudantes de um curso de metodologia do ensino da leitura rejeitavam as ideias do formador centradas sobre o aluno e o processo, e isso com base em suas crenças preexistentes quanto ao "bom ensino", aos "bons temas de aula", etc. 0 autor chega à conclusão de que há uma primazia das crenças pessoais dos estudantes sobre as novas metodologias ou formas de pensar preconizadas pelos formadores. Outras pesquisas mostram que as crenças iniciais se veem reforçadas onde se quer modificá-las (ver, por exemplo, FEIMAN-NEMSER; BUCHMANN, 1989).

Uma série de estudos mediu o impacto de cursos especialmente concebidos para mudar as crenças dos futuros professores. Nesses, os pesquisadores eram, frequentemente, eles mesmos formadores. Dentre essas pesquisas, mencionaremos as de Ball (1989), Civil (1993) e as de Simon e Mazza (1993). As três mostram que as crenças de um certo número de estudantes não se modificam na direção esperada. Os autores questionam a possibilidade de mudar as crenças em um curso ou mesmo em um programa. Os resultados de Feiman-Nemser e Buchmann (1989) são mais encorajadores. Esses pesquisadores avaliaram a mudança de crenças de 91 estudantes após um curso dado no início da formação e concluíram que ele teve impacto em diferentes níveis. No final do curso, os estudantes consideram que o ensino é mais complexo do que o que eles pensavam inicialmente e a ligação entre o ensino e a aprendizagem começa a ser percebida por eles. Da mesma maneira, os resultados de pesquisas realizadas por McDiarmid (1990) mostram que, quando os cursos de pedagogia tentam explicitamente pôr em discussão as crenças prévias dos futuros professores, mudanças podem ocorrer e ocorrem efetivamente. $\mathrm{O}$ autor percebe, no entanto, que as crenças de professores se revelam extremamente difíceis de mudar; como consequência, ele se mantém cético quanto ao impacto que podem ter tais cursos, em particular no que se refere à sua transferência para as práticas dos estudantes. 
Estudos sobre o efeito dos estágios e do ingresso no magistério sobre as crenças dos professores

Como já indicado, na formação a dimensão prática é importante aos olhos dos estudantes. Eles esperam mais dos seus estágios do que dos cursos, estimando que é principalmente, ou até exclusivamente, a experiência na prática que é formadora (cf. principalmente BOOK; BYERS; FREEMAN, 1983; CRAHAY; ORY, $2006^{31}$; RICHARDSON-KOEHLER, 1988, citados porRICHARDSON, 1996). Quanto a saber se o tempo vivido em sala de aula contribui para a transformação dos estudantes em formação, a síntese dos estudos está longe de ser encorajadora. Os trabalhos de Hoy (1967) e de Hoy e Woolfolk (1990) mostram que os estudantes iniciam a formação com crenças relativas ao seu papel de professores orientadas para o controle (importância de manter a disciplina e de controlar os alunos). Eles mudam - ao menos em aparência - ao longo da formação, evoluindo para uma posição mais humanista. No entanto, quando os futuros professores fazem estágios, eles “invertem" suas crenças para uma posição mais rígida. Os autores levantam a hipótese de que essa mudança é devida à existência de uma ideologia de controle presente nas escolas, que afeta os estudantes por meio do processo de socialização.

Com base nesses trabalhos, Cochran-Smith (1991) sugere que os estagiários são marcados pelos anos passados na escola como alunos, uma ideia desenvolvida anteriormente por Lortie (1975). Mesmo que eles expressem opiniões humanistas durante os cursos de formação, suas crenças preexistentes, advindas essencialmente da experiência escolar pregressa, prevalecem quando eles encontram a realidade das salas de aula durante os estágios. Assim, as experiências no contexto escolar reforçariam as crenças que os professores em formação adquiriram por ter sido alunos. Nesses estudos nos damos o direito de nos interrogar sobre a profundidade das transformações das crenças geradas ao longo da formação teórica.

Leavy, McSorleye Boté(2007) estudaram, ao longo do primeiro ano deformação, a evolução das crenças de dois de grupos de estudantes sobre o ensino e a aprendizagem, por meio de suas metáforas sobre o tema. Os estudantes do primeiro grupo tiveram cursos de metodologia, sessões de microensino e atividades reflexivas durante o primeiro semestre. Em seguida, no decorrer do segundo semestre, realizaram estágios de um dia por semana, alternados

${ }^{31}$ No estudo de Crahay e Ory (2006), os formadores em psicopedagogia das HEP (Haute École Pédagogique) estão convencidos de que seus estudantes possuem neles essa ideia ancorada. 0 estudo evidencia que os formadores subestimam sua influência sobre os estudantes. 
com momentos de reflexão sobre a prática. O segundo grupo também teve cursos de metodologia, mas não realizou estágios. Os resultados mostram que, no final da experiência, as metáforas behavioristas que prevaleciam no início do ano continuam dominantes entre os estudantes do primeiro grupo. Já nos estudantes do segundo grupo, as metáforas behavioristas são menos numerosas que as metáforas construtivistas no final do primeiro ano de formação. De acordo com os autores, a mudança significativa observada no segundo grupo é prova do potencial que as aulas têm de influenciar as crenças, enquanto a manutenção das metáforas behavioristas no interior do primeiro grupo seria associada à experiência de sala de aula em estágio, que “apaga" os efeitos das aulas anteriores ${ }^{32}$. Esses autores, que postulam que os professores devem evoluir para crenças construtivistas, levantam a hipótese de que esses estudantes não se beneficiaram o suficiente das oportunidades de reflexão sobre a forma como os conceitos ensinados está ligada às realidades das salas de aula. Por conseguinte, não puderam proceder a uma articulação em profundidade de suas teorias e experiências de estágio. De acordo com os autores, a prática reflexiva ofereceria a possibilidade de preencher eficazmente o vazio entre a teoria e a prática profissional. Retomaremos esse estudo na discussão.

Doudin, Pfulg, Martin e Moreau (2001) estudaram as concepções dos estudantes e dos professores sobre a inteligência e sobre o papel do professor nas dificuldades de aprendizado e no fracasso escolar. Sua análise atesta, na maior parte dos casos, uma significativa coerência entre as duas categorias de concepções. Ela mostra que estudantes e professores se diferenciam entre si por seus perfis de respostas. Os pesquisadores observam uma evolução dos perfis de respostas em razão do avanço dos estudantes no percurso de formação e da experiência profissional dos professores em atividade. No conjunto, os estudantes apresentam uma concepção mais socioconstrutivista da inteligência, assim como um forte compromisso diante das dificuldades de aprendizagem e do fracasso escolar. Esse perfil é, entretanto, mais marcado nos estudantes que iniciam a formação e não realizaram ainda o estágio prático. Os estudantes que realizaram ao menos um estágio se caracterizam principalmente pelas concepções heterogêneas. Ao contrário dos futuros professores, os docentes em serviço possuem uma concepção mais inatista da inteligência e um envolvimento moderado em relação às dificuldades e ao fracasso escolar dos alunos. Dentre eles, os iniciantes (um a cinco anos de experiência) têm um ponto de vista socioconstrutivista da inteligência,

Não podemos também excluir um efeito das crenças dos professores em serviço que são acompanhados durante os estágios. 
mas não se comprometem com a luta contra o fracasso escolar. Os mais experimentados (mais de 15 anos de experiência) são os mais coerentes: eles se caracterizam por concepções inatistas e também não se envolvem. Os professores medianamente experimentados apresentam da mesma forma um envolvimento fraco, embora se declarem socioconstrutivistas.

De acordo com Doudin e seus colegas (2001), tais resultados refletem uma sequência de desenvolvimento quanto à evolução das concepções do estudante e do professor durante sua vida profissional. Eles identificam três fases ou experiências-chave: primeiro, os estágios desestabilizam as concepções dos estudantes; em seguida, a entrada na profissão leva a uma ausência de envolvimento do professor com as dificuldades dos alunose, enfim, a prática profissional favorece a instalação progressiva de uma concepção inatista da inteligência. Para explicar essas mudanças, especialmente no que se refere aos estágios, os autores levantam a hipótese de que a confrontação das concepções socioconstrutivistas dos estudantes com as concepções inatistas dos professores experimentados leva a um distanciamento das teorias ideais defendidas na formação. Assim, o contato com a prática teria “um efeito desestabilizador, até mesmo regressivo" (DOUDIN et al., 2001, p. 180). Ao entrar na vida profissional, o jovem professor tende a se confrontar com as normas do local: "O processo de socialização e de identificação com as concepções do grupo de profissionais comprometidos no momento dos estágios continua com a entrada na prática” (DOUDIN et al., 2001, p. 181). No decorrer da profissão, a passagem progressiva a uma concepção inatista da inteligência constitui um refúgio para os professores, permitindo que eles apontem "culpados exteriores" para explicar as dificuldades ou os fracassos dos alunos, o que evita o questionamento de sua eficácia como professores. Dito de outra forma, as crenças inatistas assumiriam uma função justificadora que permite legitimar a ausência de compromisso diante das dificuldades dos alunos. Como conclusão, os autores insistem na importância de ações de formação contínua, para evitar que os esforços realizados na formação para agir sobre as concepções e as práticas sejam reduzidos a nada.

Desses resultados resulta uma hipótese, formulada de forma mais ou menos explícita por todos esses autores. Os cursos dados na formação inicial podem, em certa medida, influenciar as crenças do futuro professor, e até mesmo mudálas. Entretanto, o contato com o mundo do ensino por ocasião dos estágios suplantaria o efeito dos cursos. Quanto à entrada na vida profissional, seu efeito parece deletério para as concepções psicopedagógicas que a formação inicial se esforçou por criar. Definitivamente, parece que a formação teórica 
dada aos futuros professores está prensada entre a influência persistente da sua experiência escolar como alunos, em um primeiro momento e os efeitos acumulados da socialização proveniente dos estágios, seguidos da entrada na profissão. Isso explicaria a influência limitada da formação inicial sobre as concepções dos professores.

O estudo desenvolvido por Hausoul (2005) aponta no mesmo sentido. Ele encontrou, após três anos da entrada na profissão, professores que se beneficiaram, em seu último ano de formação inicial, de uma ação de formação intensiva que visava a sensibilizá-los para os efeitos potencialmente negativos da reprovação. 0 autor constatou que os estudantes cujas concepções sobre a reprovação tinham evoluído em decorrência dessa formação persistem em duvidar da eficácia de tal prática pedagógica. No entanto, eles declaram tomar tantas decisões efetivas de reprovação quantas seus colegas de formação que não se deixaram convencer, além do que, também apresentam taxas de fracasso escolar de acordo com o padrão particularmente elevado na comunidade francesa da Bélgica. Se a ação de formação parece ter tido um efeito persistente sobre as concepções de certos professores em relação à reprovação, ela não lhes deu armas para resistir à "lei do meio". Definitivamente, é preciso reconhecer que existem poucos dados atestando os efeitos produzidos pela formação inicial dos professores.

As lições dos estudos relativos ao desenvolvimento da equipe

Richardson (1996) sustenta que a dificuldade de mudar as crenças dentro dos programas de formação inicial está relacionada à falta de prática dos estudantes no que se refere ao ensino, e, portanto, à dificuldade de ajudálos a relacionar suas crenças à sua prática. Essa autora comparou os resultados de estudos sobre a mudança das crenças de futuros professores aos resultados de professores experientes. Constata que a mudança é mais fácil de ser promovida e realizada de maneira efetiva entre os professores em exercício dentro dos programas de desenvolvimento profissional quando estes conseguem que os docentes relacionem suas crenças e conhecimentos à sua prática pedagógica. Além disso, ainda segundo a pesquisadora, muitas pesquisas chegam à constatação de uma transferência para a prática. Ela levanta então a hipótese de que um fator primordial para explicar essa diferença está ligado à experiência como professor: "O conhecimento prático, profundo, detido pelos professores experimentados é fortemente ligado à ação, e é essa ação que é percebida por eles como o centro do interesse da mudança” (RICHARDSON, 1996, p. 114). 
Richardson e Placier (2001) retomam essa tese e a examinam sistematicamente em relação aos estudos anglo-saxões sobre os efeitos de ações visando a promover o desenvolvimento profissional docente. Segundo tais autores, esse campo se estruturou sob uma oposição conceitual explicitada por Chin e Benne (1969). Em uma obra clássica, esses autores distinguem três estratégias de inovação. A primeira (que pouco diz respeito à discussão a seguir) é intitulada poder coercitivo. Como o nome indica, trata-se de impor uma mudança por decreto ou lei, e, frequentemente, de operar sobre as relações de força entre os indivíduos e/ou grupos de indivíduos; os movimentos não violentos como aqueles inspirados por Gandhi são enquadrados nessa categoria. As abordagens empírico-racionais constituem a segunda categoria. Elas geralmente têm suas bases no saber proveniente de pesquisas científicas, que se quer disseminado de tal maneira que inspire as ações dos profissionais. 0 procedimento é de cima para baixo e está enraizado em uma concepção racional do ser humano: se ele conhece a "verdade" científica, ele se empenhará em levar em consideração o saber recentemente adquirido em seu agir profissional. Por fim, a abordagem normativa reeducativa baseia-se na ideia de que os indivíduos agem em função de normas socioculturais: toda mudança de crença e/ou de práticas, mesmo que pouco importante, requer uma transformação em profundidade de normas cognitivas e comportamentais que implica o indivíduo em suas relações e no seu entorno social.

Em nosso campo, as abordagens empírico-racionais conheceram uma primeira onda ligada às pesquisas processo-produto (CRAHAY, 2006). Tratava-se, na época, de disseminar as habilidades de ensino, igualmente designadas como competências, cujas pesquisas empíricas tinham mostrado a eficácia quanto à aprendizagem dos alunos. Sparks e Loucks-Horsley (1990, citados por RICHARDSON; PLACIER, 2001) destacam que esses dispositivos são baseados em um modelo de formação que postula, por um lado, que certos comportamentos e/ou técnicas são dotados de tal valor que merecem ser generalizados e, por outro lado, que qualquer professor ou estagiário é susceptível de se apropriar e de reproduzir esses comportamentos e/ ou técnicas. Com a revolução cognitiva cuja importância já recordamos, as abordagens empírico-racionais se estenderam aos conhecimentos e às crenças dos professores. Quer se trate de modificar comportamentos ou crenças, as intervenções de formação no âmbito dessa corrente de ideias são de curta duração. Por exemplo, Sparks (1988, citado por RICHARDSON; PLACIER, 2001) analisa os efeitos de uma intervenção de cinco encontros sobre as crenças e as práticas de 19 professores de ensino fundamental II. Em outro exemplo, Krajcik, Layman, Starr e Magnusson (1991, citados por RICHARDSON; 
PLACIER, 2001) examinam os efeitos de uma sessão de formação de verão que se estendeu por três semanas. Nesses estudos se observam efeitos de curto prazo sobre as crenças e as práticas de certos professores.

A eficácia no longo prazo dessas abordagens não é assegurada. Isso é atestado pelo estudo de Stallings e Krasavage (1986, citados por RICHARDSON; PLACIER, 2001) que acompanha durante quatro anos professores do ensino fundamental II que receberam formação intensiva sobre a maneira de gerir o tempo escolar da melhor forma. Inicialmente, o programa de formação comportava três modalidades. Na primeira, apenas os professores encarregados do ensino da leitura recebiam formação, enquanto a segunda abrangia, além dos professores encarregados da leitura, aqueles responsáveis pelas artes e pela linguagem; já na terceira, todos os professores da escola participavam. De maneira geral, essa formação provou-se eficaz tanto em termos da implantação das estratégias comportamentais recomendadas aos docentes quanto em termos do êxito dos alunos nos testes de rendimento. Além disso, os efeitos mais importantes são observados em relação à terceira modalidade (em seguida à segunda e, por fim, à primeira). Essa observação conduz Stallings (1989) a destacar a importância de envolver o conjunto dos professores da escola nos programas de formação contínua quando se deseja que ela apresente o máximo de frutos. Entretanto, três anos mais tarde, os efeitos dessa formação, inicialmente eficaz, se desvaneceram em um bom número de professores.

A partir de então, produziu-se grande consenso entre os pesquisadores no que se refere às condições de eficácia das estratégias de desenvolvimento profissional, devido ao trabalho de síntese de diferentes autores (cf. RICHARDSON; PLACIER, 2001, para uma lista). Fullan (1990) as resume da seguinte maneira:

- - o programa de formação deve envolver o conjunto dos professores da escola, favorecer o colegiado e focar nos problemas encontrados em seu contexto;

- - o diretor do estabelecimento deve encorajar o processo de trabalho e se comprometer com ele;

- - o programa deve ser de longo prazo e se basear em fontes orçamentárias que permitam a compra do material necessário, a substituição dos professores quando eles estão em formação, o convite aos especialistas, etc.;

- - o conteúdo do programa de formação deve ter fundamento em pesquisas recentes, feitas com metodologia rigorosa. 
A liberdade de se comprometer com o processo de mudança é considerada por alguns autores, e não por outros. Essas características se encontram com maior frequência nas intervenções da abordagem normativa reeducativa. Richardson e Placier (2001) evocam 12 projetos com essa abordagem. Deles propomos um quadro sinótico situado no Anexo $2^{33}$. Constata-se, de imediato, que a maioria dos projetos diz respeito ao ensino de matemática ou de ciências. Além disso, quase todos são de orientação construtivista. Da mesma maneira que ao tratar dos estudos relativos aos efeitos da formação inicial, é preciso observar que a amplitude dos estudos é extremamente variável, indo de três professores à cerca de 40. A partir das análises dessas pesquisas, Richardson e Placier (2001) obtêm argumentos em favor da eficácia da abordagem normativa reeducativa. De modo mais preciso, os dois autores destacam a importância de vários componentes dessa abordagem, cuja conjugação lhes parece determinante ${ }^{34}$ :

- - os professores devem começar a apreender suas crenças ou pressupostos implícitos. Esse processo de apreensão é favorecido pelo diálogo, em especial com aqueles que compreendem o que é o ensino e conhecem o contexto particular no qual os profissionais trabalham;

- - o diálogo na comunidade de professores parece constituir o elementochave (ver MCLAUGHLIN, 1994), especialmente no início do processo evolutivo. Desse ponto de vista, a confiança na comunidade é crucial: o professor deve se sentir confiante para poder expor seus problemas, discutir suas práticas ineficazes e aceitar sua responsabilidade (ao menos parcial) nas falhas de funcionamento observadas;

- - em uma fase posterior, é importante que o professor questione suas crenças, perguntando-se quais seriam a origem, o motivo e a validade delas. É preciso que ele considere que pode modificá-las. Quando o professor está nesse estágio, a discussão com outro significativo (um amigo crítico) pode se revelar fecunda. Este pode oferecer outra linguagem que ajude a desvendar as crenças implícitas e abra novas perspectivas de reflexão sobre a prática.

\footnotetext{
Os anexos não foram traduzidos nesta versão do texto. Os originais podem ser consultados na versão eletrônica do artigo disponível em: 〈https://rfp.revues.org/2296〉.

34 Eles escrevem: "To conclude, a number of aspects of a normative-educative staff development process work to enhance learning and change" (RICHARDSON; PLACIER, 2001, p. 921). No entanto, nós não encontramos provas dessa afirmação.
} 
Afinal, as crenças e os conhecimentos dos professores são modificáveis?

Embora numerosas pesquisas nessa área se baseiem em métodos pouco precisos e apresentem dados frágeis, uma resposta positiva pode ser dada a essa questão essencial. Convém, entretanto, acrescentar, desde já, que esse processo não é óbvio. Dito de outra forma, ele requer certas circunstâncias que seríamos tentados a qualificar como excepcionais. Extensamente tratada na literatura, a temática da resistência dos professores à mudança, ou da sua impermeabilidade aos processos de formação, demonstra a dificuldade de modificar suas crenças e seus conhecimentos.

A tese defendida por Richardson e Placier (2001) interpela a questão por si mesma. A partir de revisões da literatura, os autores concluem que as crenças e os conhecimentos dos professores não mudam, ou ainda, mudam raramente em decorrência da formação inicial. Não obstante, evoluções são observáveis nos professores em exercício, seja de forma “natural”, seja independentemente de qualquer processo de formação em serviço, seja quando essas formações se inscrevem em uma abordagem do tipo normativa reeducativa. Ora, examinando detidamente os dados dos estudos que reportam as evoluções ditas naturais, essas não têm nada de natural. 0 desenvolvimento notável de Kerrie Baughman foi acompanhado no dia a dia pela solicitude de um observador pessoal (BULLOUGH; BAUGHMAN, 1997). Quanto a Russell (1995), ele pôs suas concepções de formador de professores à prova diante da realidade a fim de mostrar a legitimidade de suas convicções de formador. Obviamente, não se trata de ignorar esses estudos notáveis; convém antes enfatizar o seu caráter excepcional e, portanto, não generalizável ao comum dos professores. Quanto aos estudos que tratam do desenvolvimento da equipe, todos os autores terminam, de uma maneira ou de outra, indicando a dificuldade de fazer que as crenças e os conhecimentos dos professores evoluam. Isso requer as condições que Fullan (1990) sintetizou de forma excelente e essas devem - pensamos - ser completadas por aquelas distinguidas por Richardson e Placier (2001), no que se refere às abordagens normativas reeducativas. Nesse estágio da discussão, parece importante apontar duas dessas condições: a evolução das crenças e conhecimentos se opera primeiro no longo prazo e, também, quando o conjunto de professores da escola está envolvido e, ainda melhor, quando os docentes constituem uma comunidade de diálogo. 
Raros são os pesquisadores que julgam ser possível fazer que as crenças dos professores evoluam no curto prazo. Esses - pensamos em Guskey (1986), Mevarech (1995), Prawatt (1992) e Sparks (1988) - se inscrevem na abordagem empírico-racional da mudança; por sua vez, tais pesquisadores estão, antes de tudo, envolvidos com a implementação de novas práticas ligadas seja à pedagogia do domínio (GUSKEY, 1986), seja ao ensino de matemática (PRAWATT, 1992; SPARKS, 1988), seja aos dois (MEVARECH, 1995). Além disso, eles sustentam que é mais eficaz mudar as práticas antes de mudar as crenças. Esse ponto de vista não é partilhado por Richardson e Placier (2001), que lembram o estudo de caso realizado por Richardson, Anders, Tidwell e Lloyd (1991): o professor observado modificou em profundidade suas crenças sobre a compreensão em leitura antes de transformar sua prática de ensino. Essa problemática é crucial. Infelizmente, não encontramos estudos que a tratem de maneira séria e aprofundada e cheguem a uma ou algumas resposta(s) clara(s) ${ }^{35}$. A dificuldade de induzir mudanças nas crenças dos professores e, correlativamente, em suas práticas, merece que investiguemos as razões dessa resistência aos procedimentos de formação.

Algumas hipóteses sobre a relativa impermeabilidade das crenças dos professores aos processos de formação

Numerosos são os autores que evocam a pesquisa realizada por Lortie (1975) para explicar a resistência das crenças iniciais dos estudantes ao processo de formação. Isso se dá em Bullough e Knowles (1990, 1991), em Knowles (1992), em Borko e Putnam (1996), em Richardson e Placier (2001) e em muitos outros ainda. Sobre o tema, Bullough e Knowles $(1990,1991)$ realizaram um estudo longitudinal da identidade profissional de sete estudantes durante seu primeiro ano de formação. Baseando-se em dados sobre cinco deles, Knowles (1992) mostra que os modelos mais influentes na construção da imagem de si mesmos como professores são os modelos que intervieram cedo na sua escolaridade. 0 autor percebeu que as experiências vividas ao longo

35 A questão não é simples, pois nos parece que, em certos casos, o pesquisador não tem escolha. Como mudar as práticas dos professores em matéria de reprovação sem mudar previamente, ou de maneira concomitante, suas crenças? Impondo-lhes essa mudança por um tipo de decreto? Mas a imposição dessa prática corre o risco de induzir uma hostilidade que será preciso vencer; as experiências realizadas na comunidade francesa da Bélgica comprovam esse risco (CRAHAY; DONNAY, 2001). Parece-nos, por sua vez, desejável modificar as práticas dos professores no que se refere ao ensino da leitura recorrendo a manuais escolares e, em seguida, trabalhar na mudança de crenças. Enfim, no caso do ensino da leitura, parece possível comparar duas estratégias de mudança das práticas e das crenças, uma começando pelas práticas e outra pelas crenças. Pelo que sabemos, esse tipo de estudo ainda não foi realizado. 
da formação têm muito pouco impacto sobre o processo identitário, assim como sobre os comportamentos durante os estágios. Por suas conclusões, Knowles (1992) reforça a tese de Lortie (1975), segundo a qual os milhares de horas passadas por cada estudante nos bancos da escola durante toda a escolaridade influenciam fortemente a construção das crenças dos futuros professores, mas também - pode-se supor - as de seus pais e de todo indivíduo que foi escolarizado. Essas crenças, construídas precocemente, têm a tendência de se perpetuar e seriam refratárias à mudança.

Para fundamentar a ideia de uma influência precoce dos modelos encontrados nas salas de aula, Pajares (1992, p. 322) cita Van Fleet (1979), que descreve uma visita ao seu irmão em que ele vê a sobrinha de 8 anos brincando de “ser professora”. De acordo com a descrição do pesquisador, a criança estava em seu quarto, circundada por bonecas e parada à frente do quadro negro: "Posta ali, com o giz que se balançava com perfeição entre os dedos, com boa entonação e a expressão do rosto adequada, ela ensinava, exortando as bonecas a ficarem especialmente atentas durante essa lição importante (VAN FLEET, 1979, p. 283). E Pajares (1992) comenta: “

A garotinha Van Fleet estava desenvolvendo um conjunto de crenças e de práticas ligadas ao que é ser professor. Independentemente do adulto que ela poderia se tornar, durante ao menos os próximos dez anos ela afinaria suas práticas e reforçaria suas crenças florescentes, isso se elas já não estivessem enraizadas (PAJARES, 1992, p. 322).

Esse posicionamento teórico derrotista tem sentido porque se admite comumente que quanto mais cedo uma crença é incorporada na estrutura cognitiva de um indivíduo, mais difícil será desalojá-la. Já as crenças recentemente adquiridas são mais vulneráveis à mudança. Segundo Nisbett e Ross (1980), é preciso contar com um efeito de primazia, segundo o qual as crenças construídas a partir de experiências da tenra idade influenciam as interpretações e as percepções ulteriores. Com o tempo, os indivíduos constroem para si teorias pessoais robustas, que persistem mesmo em face de explicações contraditórias lógicas, convincentes ou até mesmo cientificamente fundadas. Fenômenos de perseverança se instalam com base em diversos processos cognitivos, tais como a percepção seletiva das informações e até mesmo sua deformação (SCHOMMER, 1990): os elementos que sustentam as crenças anteriores são levados em conta, enquanto os elementos conflituosos são ignorados ou deformados. As crenças influenciariam também a memória: os indivíduos se lembram de certos eventos, deformando-os se necessário, para sustentar suas crenças (NISBETT; ROSS, 1980). 
Em conformidade com essa teoria geral sobre o funcionamento das crenças, é lógico pensar que o leque de crenças que os estudantes forjam para si ao longo de suas experiências como alunos está solidamente ancorado no momento em que eles ingressam na formação inicial para se tornar professores (PAJARES, 1992; STRAUSS, 1996, citado por WOOLFOLK HOY; MURPHY, 2001; RICHARDSON, 1996; WILSON, 1990). Ademais, reconhecer a solidez da ancoragem das crenças iniciais não implica, por outro lado, admitir que elas sejam inextirpáveis: certos autores parecem, frequentemente de maneira implícita, fazer essa passagem. Talvez convenha reconhecer, ao mesmo tempo, o enraizamento sólido dessas crenças e a necessidade de dispositivos de formação que ataquem de frente as crenças que se desejam modificar. Nesse sentido, Richardson (1996) observa que os conhecimentos psicopedagógicos instituídos são apresentados aos futuros professores segundo um processo de aprendizagem explícito, enquanto as crenças iniciais deles são de natureza implícita, sedimentadas desde a infância pela conjunção de aprendizados vicários e interações verbais ao longo dos quais as crenças psicopedagógicas do senso comum são reforçadas.

Referindo-se, aliás, à noção de centralidade de certas crenças em relação a outras, desenvolvida por Rokeach (1976), Richardson (1996) levanta a hipótese de que certas crenças psicopedagógicas, as mais centrais, seriam mais resistentes à mudança que outras. Apresentando mais conexões que as outras crenças do sistema, tais crenças ou concepções centrais requereriam mais esforços para evoluir. Assim, seria conveniente considerar que as mudanças de crenças no curto ou longo prazo são ligadas à centralidade. Rokeach (1976) formula a hipótese de que "as mudanças induzidas no nível das crenças centrais têm repercussões relativamente maiores sobre o resto do sistema de crenças do que as mudanças induzidas no nível de crenças menos centrais" (p. 55).

Do nosso ponto de vista, a reflexão teórica de Richardson (1996) relança 0 debate. No plano da pesquisa, isso implica estudos sobre a estruturação das crenças dos professores. De acordo com o modelo conceitual de Rokeach (1976) retomado por Richardson (1996), certas crenças seriam mais centrais do que outras. De maneira geral, esse modelo conceitual sugere uma estruturação das crenças em estratos superpostos: existiriam camadas superficiais e profundas. Essa concepção se opõe à de Green (1971), que sugere que as pessoas podem organizar suas crenças em clusters (agrupamentos, conjuntos de crenças) mais ou menos isolados uns dos outros ou, até mesmo, totalmente desprovidos de relações entre eles. Assim os professores podem manter, 
implicitamente ou não, crenças que podem parecer contraditórias aos olhos dos pesquisadores. Por exemplo, Van Driel, Bulte e Verloop (2007) estudaram as relações entre as crenças dos professores do ensino fundamental II e do ensino médio sobre, por um lado, o ensino-aprendizagem e, por outro lado, os objetivos que o programa oficial de educação em química deveria alcançar. Eles diferenciaram os respondentes em razão de suas estruturas de crenças. Quatro grupos de professores foram identificados, dos quais o maior (45\% dos participantes) combina duas orientações contraditórias quanto ao ensinoaprendizagem e aos objetivos do programa oficial: uma orientação relativa ao ensino-aprendizagem centrada na matéria, e outra relativa ao programa, caracterizada por uma oposição à ideia segundo a qual os conceitos teóricos devem ser ensinados com prioridade. Ainda segundo esses autores, "alguns professores combinam deliberadamente diferentes ideias sobre o ensino, pois eles acham que essas diferentes perspectivas podem ser úteis nas diferentes situações de ensino. Outros, aparentemente, ignoram as diferenças e possuem, às vezes, incoerências em seus sistemas de crenças" (VAN DRIEL; BULTE; VERLOOP, 2007, p. 169). A pesquisa de Issaieva e Crahay (2010), que trata em especial das concepções de avaliação dos professores franceses do fim do ensino primário, chega a constatações análogas: os professores combinam, de maneira mais ou menos coerente, crenças favoráveis a uma abordagem formativa da avaliação com outras, de uma perspectiva normativa.

A questão da estruturação das crenças nos parece crucial e, ao mesmo tempo, grandemente subexplorada. Conhecimentos validados nessa área seriam úteis tanto para conceber programas de formação quanto para interpretar os resultados das pesquisas sobre o tema. Atualmente são postos em um mesmo plano todos os estudos que tentaram induzir a uma mudança de crenças. Se a tese defendida por Rokeach (1976) e retomada por Richardson (1996) é exata, os sucessos e os fracassos de formação não deveriam ser todos considerados da mesma maneira. Assim, segundo essa hipótese teórica, as formações visando às mudanças de crenças de superfície deveriam atingir mais facilmente seus objetivos, mas os efeitos obtidos deveriam ser mais suscetípveis de se desvanecer, mesmo em curto prazo. No sentido inverso, as formações visando à transformação de crenças centrais deveriam encontrar mais resistências ao longo do processo, mas os efeitos, uma vez gerados, deveriam se manter no longo prazo e repercutir sobre outras crenças. Se, ao contrário, é o modelo de Green (1971) que se aproxima mais da realidade psicológica, a transformação das crenças pode ser abordada quase por qualquer ângulo; somente se trataria de levar em conta os pacotes de crenças que se aglutinam em clusters. Afinal, defendemos que a agenda das 
pesquisas futuras reserve um lugar importante para o estudo da estruturação das crenças.

Enfim, parece necessário levar em consideração o que são as preocupações mais importantes dos professores em formação. As pesquisas sobre os estágios de desenvolvimento dos docentes são unânimes e explícitas sobre esse aspecto: sua preocupação primeira é o manejo da sala de aula. Os professores em formação e iniciantes querem provar seu valor diante da classe (cf. particularmente FULLER; BOWN, 1975). Pode-se inferir que as teorias de aprendizagem e do desenvolvimento psicológico das crianças não estão no centro dos interesses primeiros dos professores nesse momento de sua evolução. Daí decorre uma hipótese, em si banal, baseada na ideia de uma sucessão "obrigada" das transformações a operar nos professores: certas mudanças de crenças deveriam necessariamente preceder outras. Para apoiar essa hipótese, convocamos Hollingsworth (1989), que, observando como os estudantes em formação se apropriam do ensino da leitura, constata que eles devem dominar as técnicas de condução da classe antes de poder trabalhar suas crenças pedagógicas e, mais particularmente, as crenças pedagógicas de conteúdo.

As crenças iniciais dos professores: um filtro a ser considerado na concepção das formações

Diversas pesquisas (HOLLINGSWORTH, 1989; KAGAN, 1992; BORKO; PUTNAM, 1996; RICHARDSON, 1996; RICHARDSON; PLACIER, 2001) mostraram a influência das crenças no processo de formação inicial. Evidentemente, os futuros professores não iniciam sua formação "do nada". Como mostrado extensamente, os professores possuem crenças que influenciarão não apenas suas práticas, mas igualmente o que eles aprenderão e a maneira como aprenderão. Ora, em virtude do mecanismo bem conhecido em psicologia da percepção seletiva das informações (TVERSKY; KAHNEMAN, 1974), o futuro professor interpreta e avalia suas experiências de formação por meio do prisma de suas crenças, quer se trate de cursos teóricos, de práticas recomendadas ou de suas experiências de estágio. Por exemplo, Feiman-Nemser e Buchmann (1989) apresentam o caso de uma estudante que, influenciada por suas crenças iniciais, não retém, ao realizar as leituras recomendadas, os elementos de informação que vão contra suas crenças. Ela chega a modificar - inconscientemente - a mensagem veiculada pelo texto para que corresponda a suas crenças. De maneira geral, os autores sugerem que os textos apresentados aos estudantes e, mais amplamente, que todo ensino pode produzir um efeito inverso ao procurado ou esperado pelos 
formadores, na medida em que todo estudante interpreta as informações que Ihe são apresentadas usando suas crenças, esforçando-se para conservá-las ou até mesmo reforçá-las ${ }^{36}$.

Ross, Johnson e Smith (1991, citados por BORKO; PUTNAM, 1996, e por RICHARDSON, 1996) estudaram a influência das crenças e conhecimentos dos futuros professores sobre o que eles podem aprender na formação. 0 programa chamado Proteach tinha como eixo específico o desenvolvimento de capacidades reflexivas e de uma base de conhecimentos relativa ao ensino. Tendo realizado vários estudos acerca do impacto das atividades de formação sobre as reflexões e as práticas dos estudantes, os pesquisadores concluem que, dentre as múltiplas facetas que influenciam a aprendizagem do ensino, as crenças existentes no ingresso na formação são das mais significativas. Da mesma maneira, Hollingsworth (1989), estudando o impacto de um programa de formação de orientação construtivista sobre as crenças relativas à aprendizagem, observa que as mudanças produzidas dependem das crenças iniciais dos estudantes e que os mais aptos a confrontar suas crenças com as teorias ensinadas construíram conhecimentos mais profundos.

As crenças dos professores preenchem, portanto, uma função epistêmica. Mais particularmente, elas são susceptíveis de operar como um filtro através do qual os fenômenos, as informações são selecionados e interpretados. A literatura relativa à introdução de práticas inovadoras ou à utilização de novos programas (por exemplo, BORKO; PUTNAM, 1996; OLSON, 1980, 1981, citados por CLARK; PETERSON, 1986; RICHARDSON, 1990) ilustra bem esse mecanismo. Assim, em um programa de pesquisa, o California Study of Elementary Mathematics, que trata da mudança de práticas dos professores em decorrência das novas diretivas nacionais em matéria de ensino, Cohen (1990) apresenta o caso de um professor. Este dividia seus alunos em pequenos grupos para responder à demanda dos órgãos de educação de seu estado, com vistas a praticar mais o ensino cooperativo. No entanto, se a organização da classe era modificada fisicamente, o conteúdo e o contexto das interações em sala de aula não mudavam. 0 professor interagia com os alunos individualmente ou com a classe inteira, sendo que deveria ter encorajado as interações diretas entre os alunos. Esses chegavam a ficar desanimados. Em resumo, a forma como o professor interpretava e executava as novas diretivas passava pelo filtro de suas crenças referentes ${ }^{36}$ É possível estabelecer um paralelismo com os trabalhos em psicologia social de abordagem cognitivista. Lembremos especialmente dos trabalhos de Lord, Ross e Lepper (1979), que mostram que estudantes com atitudes opostas podem encontrar em um mesmo texto argumentos que os apoiem em sua posição. 
às interações com os alunos. Esse tipo de resultado sugere, por um lado, que antes de toda inovação é essencial examinar tais filtros e, por outro lado, que as mudanças no nível das práticas devem ser acompanhadas de mudanças no nível das crenças (CLARK; PETERSON, 1986; BORKO; PUTNAM, 1996; VAN DRIEL; BULTE; VERLOOP, 2007).

Reconhecendo a importância das crenças iniciais dos professores em formação, numerosos autores (dentre eles CRONIN-JONES, 1991; FENSTERMACHER, 1979; PAJARES, 1992; OLSON, 199337; RICHARDSON, 1996) estimam ser primordial torná-las explícitas, antes de ter como objetivo tentar modificálas. Ignorando o peso das concepções iniciais, o formador corre o risco de ver perpetuarem-se concepções e práticas de ensino obsoletas e ineficazes. Esse ponto de vista é partilhado por numerosos autores, sendo claramente explicitado por Kagan (1992). A autora aproxima as observações evocadas do que se conhece das concepções dos alunos nas áreas de ciências e matemática. Como decorrência, propõe adaptar o quadro teórico de mudança conceitual à problemática da transformação das crenças dos professores. $\mathrm{E}$ recomenda um procedimento de intervenção em três tempos:

- - ajudar os estudantes a tomar consciência de suas crenças implícitas e, falando, a explicitá-las;

- - confrontar os estudantes com os elementos que podem resultar em um questionamento de suas crenças, colocando em evidência suas contradições internas, incoerências e até mesmo inadequações em relação à realidade do ensino;

- - dar oportunidade aos estudantes de integrar novos conhecimentos de maneira a diferenciar as antigas crenças, e até de substituir as concepções totalmente inadaptadas ${ }^{38}$.

Em síntese, se trataria de suscitar um processo de desequilibração/ reequilibração, tal como teorizado por Piaget (1975) na obra A equilibração das estruturas cognitivas ${ }^{39}$.

37 Baseando-se no estudo de caso de dois estudantes, esse pesquisador mostra que eles não mudam suas crenças sobre "a boa forma de ensinar" após os cursos de formação. Ele levanta a hipótese de que se esses futuros professores persistem em manter as crenças é porque o processo de formação não lhes oferece, efetivamente, a oportunidade de confrontá-las com os conhecimentos ensinados.

38 A citação inglesa é a seguinte: "To promote conceptual change among students, teachers must (a) help students make their implicit beliefs explicit; (b) confront students with the inadequacy or inconsistency of those beliefs; and (c) give students extended opportunities to integrate and differentiate the old and the new knowledge, eliminating brittle preconceptions and elaborating anchors" (KAGAN, 1992, p. 76).

39 A edição brasileira é de 1976. (N. de T.) 
Existem melhores crenças do que outras?

A voz da desequilibração é, no entanto, problemática no que se refere às crenças dos professores, pois esse procedimento postula que existem conhecimentos mais válidos do que outros, do que decorre a possibilidade de gerar equilibrações majorantes (PIAGET, 1975). Ora, como destaca Kagan (1992), o ensino é uma área em que os conhecimentos seguramente válidos são raros. Como, então, conduzir um processo de transformação das crenças dos professores se não se tem a certeza de orientá-los para um melhor pensar e/ou um melhor agir? Por que então realizar esse trabalho de formação?

Examinando as abordagens que se inscrevem na corrente do prático reflexivo (cf. SCHÖN, 1994), Liston e Zeichner (1989, citados por KAGAN, 1992), distinguem três posições. Em um extremo, encontramos as abordagens que consideram que todas as crenças se equivalem; o processo reflexivo tem então como objetivo elucidar as preferências, mas não se trata de julgar as crenças de uns e de outros. No outro extremo, encontramos os dispositivos de formação que consideram que as crenças e os conhecimentos dos professores devem, por fim, se conformar a um conjunto de padrões profissionais, que definem as normas da profissão, sendo as normas o produto de um consenso entre os especialistas. Entre os dois extremos, encontramos abordagens que buscam que os professores estejam cientes do tipo de corrente pedagógica a que aderem (socioconstrutivismo, ensino transmissivo, etc.) e se atenham a tornar firme sua coerência própria, pouco importa a corrente escolhida.

Poucos autores levantam essas questões, embora elas sejam centrais, quer se trate de definir a finalidade de uma formação ou de avaliar as mudanças de crenças. Na maior parte dos estudos recenseados, a evolução das crenças é assimilada a um processo de substituição: no início da formação, o professor pensava $A$; no fim, ele pensa $B$. Essa forma de apresentar o problema faz todo o sentido se temos a segurança de que pensar B é susceptível de levar a melhores práticas do que pensar $A$. Mas é preciso reconhecer que, em educação, raramente estamos diante desse tipo de situação. Mesmo entre os pesquisadores em ciências da educação, é raro que exista uma unanimidade de crenças. Examinemos alguns casos precisos e os discutamos.

No estudo de Leavy, McSorley e Boté (2007), os estudantes que realizaram os estágios nas escolas possuíam, no final da formação, as crenças (apreendidas por meio de metáforas) prevalecentes no início do curso. Contrariamente, os estudantes que realizaram apenas os cursos teóricos durante o mesmo espaço de tempo privilegiaram as metáforas que refletem convicções 
socioconstrutivistas. Para os autores, é evidente que as evoluções positivas tomam a direção do socioconstrutivismo. Sem pôr em dúvida esse postulado, os pesquisadores incriminam, contudo, o processo de formação e, mais especificamente, a falta de oportunidade de reflexão sobre a maneira como os conceitos ensinados são relacionados às realidades das salas de aula. Essa hipótese é admissível, mas podemos propor uma concorrente: confrontados à dificuldade inerente a todo manejo de sala de aula, os jovens professores experimentariam o aspecto prático dos princípios behavioristas, assim como seus efeitos em curto prazo, e os integrariam à sua prática cotidiana. Porque, é preciso admitir, ninguém hoje apresentou a prova irrefutável da superioridade do socioconstrutivismo sobre o behaviorismo em termos de gestão da sala de aula. Ao contrário, certos pesquisadores contestam a eficácia do que eles consideram como uma crença comum (cf. especialmente KIRSCHNER, SWELLWE; CLARK, 2006).

As crenças dos professores de cultura francófona no que se refere à reprovação são resistentes às tentativas de desestabilizá-las (CRAHAY; DONNAY, 2001). O estudo realizado por Hausoul (2005) mostrou que professores que, ao longo de sua formação inicial, tinham mudado de crenças, podem manter essas novas crenças após três anos de exercício da profissão, utilizando a reprovação exatamente como seus colegas. Ora, nesse caso, dispomos de provas quase experimentais da ausência de efeitos positivos da reprovação (CRAHAY, 2004). Infelizmente, os professores não têm oportunidade de experimentar o que teriam sido os efeitos de uma promoção dos mesmos alunos que são reprovados ${ }^{40}$; eles se deixam impressionar pelo progresso dos repetentes e, não tendo meios de relativizar sua importância, perseveram atribuindo uma eficácia enganosa a uma prática pouco operante. Além disso, o apego dos professores à reprovação é, em parte, de natureza social. A tradição e o consenso quase unânime dos professores, pais, responsáveis, e mesmo dos alunos, pesa muito na balança: é preciso ser um herói para desafiar essa convicção de senso comum. Compreendemos então facilmente a oportunidade de oferecer - como recomenda Fullan (1990) - o programa de formação para o conjunto de professores da escola... sem ter certeza de que isso é suficiente. Pois, como argumenta Draelants (2006, 2009), a reprovação dá provas de grande funcionalidade quando o objetivo é obter classes homogêneas em termos de performance de alunos e quando a cultura escolar dominante sustenta que seleções e orientações devem ser feitas. Por

40 Recordemos que as pesquisas quase experimentais mostram que, ao longo do ano repetido, os repetentes progridem, mas menos que seus colegas de sala, igualmente fracos, que foram aprovados (CRAHAY, 2004). 
fim, as provas apresentadas pelos pesquisadores a respeito da ausência de efeitos da reprovação sobre as aprendizagens dos alunos têm bem pouco peso nesse contexto. Para se legitimar, os professores declaram: "Claro, em teoria, a reprovação não é a solução, mas na prática, é outra coisa!”

O caso do ensino da leitura fornece outro exemplo em que o que é bom de acreditar está submetido a debates perpétuos. A pesquisa em psicologia cognitiva da leitura (MARTINET; RIEBEN, 2010) demonstrou amplamente a importância da consciência fonológica e do domínio do princípio alfabético. O lugar reservado à aprendizagem do código, a maneira de conduzir essa aprendizagem e o equilíbrio de garantir atividades que mobilizem a busca do sentido continuam sendo motivo de controvérsias, muito vivas às vezes, se julgarmos o que ocorre regularmente na França sobre essas questões. Manifestamente, no que se refere à aprendizagem da leitura, a questão de boas crenças é, ao menos em parte, de natureza ideológica. É também o caso da composição das turmas. A pesquisa mostra de maneira convincente (CRAHAY, 2000; CRAHAY; MONSEUR, 2006; MONSEUR; CRAHAY, 2008) os efeitos positivos da diversidade social das turmas e da mistura de alunos fortes e fracos; essa questão é tema constante de vivas polêmicas. Nos dias atuais, apenas o ensino de matemática e de ciências parece ter escapado das controvérsias amplamente mediatizadas. É nessas áreas que as pesquisas anglo-saxônicas apresentam o maior número de sucessos em termos de evolução das crenças no sentido do construtivismo.

Em resumo, o modelo da mudança conceitual parece demasiado estreito para dar conta das transformações de crenças que parecem desejáveis de suscitar no âmbito da formação de professores. Ele é muito estritamente cognitivo para resolver os problemas postos para os formadores de docentes. Reduz a problemática a questões de fatos (ou de verdades empíricas) ignorando na prática que a educação faz também perguntas de direito (cf. CRAHAY, 2000). Também subestima os fenômenos de aplicação prática, assim como os de desejabilidade e consenso social. Este último é resolvido pelas abordagens normativas reeducativas: o consenso se negocia no interior da escola, entre professores, por meio do que McLaughlin (1994) nomeia a comunidade de diálogo. Infelizmente, essa solução não parece transferível como tal para aplicação na formação inicial dos professores.

Convém, aliás, notar que um bom número de professores ignora os resultados das pesquisas em educação. Suas crenças se elaboram, na maioria das vezes, independentemente desse saber. Essa constatação levanta diversas 
questões que mereceriam ser estudadas pelos pesquisadores. Primeiro seria interessante compreender melhor como os profissionais integram saberes validados empiricamente a suas crenças espontâneas. Esse confronto dos saberes com origens e status diferentes provoca nos docentes uma reflexão de natureza epistemológica sobre a validade das crenças? De maneira mais geral, quando os professores são postos em desequilíbrio sobre suas crenças, como eles tratam essa perturbação e, por fim, como e por que eles optam por uma crença em detrimento de outra? Eles distinguem as questões de direito das questões de fato? Dito de outro modo, há julgamento de ordem epistemológica da parte deles (cf. a síntese de CRAHAY; FAGNANT, 2008) ou a sua escolha se baseia em um processo de outra natureza? Em artigo intitulado The practicality ethic in teacher decision-making, Doyle e Ponder (1977) defendem a ideia de que os professores escolhem prioritariamente suas estratégias de ensino em função de sua personalidade e não em função da eficácia ou da validade teórica dessas estratégias. 0 que ocorre quando se questionam professores sobre o que eles consideram uma crença justa? Resumindo, parece-nos que pesquisas poderiam, e mesmo deveriam, ter por objeto de estudo como os professores estabelecem o que é uma crença válida ou, ao menos, pertinente; quando eles são levados a fazê-lo.

\section{CONCLUSÃO: A EVOLUÇÃO DAS CRENÇAS, PROCESSOS MÚLTIPLOS}

A análise das pesquisas sobre os efeitos da formação inicial e do desenvolvimento da equipe desvenda, para a maior parte dos pesquisadores, uma concepção limitada da evolução das crenças. Na maioria dos estudos, apenas parecem ser consideradas as mudanças do tipo substituição de crenças (ou seja, quando o professor passa da crença A à crença B). Na interpretação da reflexão conceitual de Leuchter (2009), somos levados a considerar que existem outros tipos de mudanças e que a substituição de crenças não é, provavelmente, a mudança que ocupa prioritariamente o campo mental dos professores. Para Leuchter (2009), as crenças dos professores se desenvolvem e evoluem em um continuum, que vai do sistemático ao situado, do explícito ao implícito, do declarativo ao procedimental, e do cientificamente fundado aos elementos baseados na experiência pessoal e profissional. Essa conceitualização considera modalidades de mudanças múltiplas, complementares à substituição de crenças.

Por meio de livros e manuais didáticos, os professores entram em contato com conhecimentos e crenças disponíveis para toda a comunidade científica. $\mathrm{Na}$ medida em que as assimilam, eles tomam para si conhecimentos e crenças 
cientificamente fundamentados. Quer sejam disciplinares, psicológicos ou pedagógicos, esses conhecimentos e crenças provenientes da pesquisa são sistematizados, transparentes, acessíveis e comunicáveis. O repertório de conhecimentos e crenças profissionais dos professores se baseia em parte nesses saberes, de caráter relativamente estável e consensual, uma vez que não estão submetidos a variações individuais (LEUCHTER, 2009). Tais saberes podem se tornar funcionais, desde que sejam ancorados nas situações e nos casos advindos da experiência do professor. Seguindo as lições da psicologia cognitiva, Leuchter (2009) destaca que não é o saber sistemático que governa o ato de ensino: os conhecimentos declarativos devem passar a ser procedimentais. É preciso considerar que existe, da parte de todo professor, um trabalho amplamente inconsciente de reestruturação dos saberes sistematizados, os quais são adquiridos essencialmente ao longo da formação inicial. Segundo a pesquisadora, essa reestruturação se efetua com base nas experiências acumuladas nas situações de interação. A reorganização leva a um distanciamento dos conhecimentos e crenças dos professores em relação aos saberes sistemáticos e a uma aproximação em relação às especificidades situacionais. Essa transformação dos conhecimentos formais em saberes procedimentais pode ser também designada pelo termo enactement, no sentido de que os conhecimentos formalizados no nível da pesquisa se transformam para "se incrustar" na prática dos docentes.

A passagem do declarativo ao procedimental é, portanto, também, uma mutação do cientificamente fundado para os elementos baseados na experiência pessoal e profissional. É ainda uma passagem do sistemático ao situado. Leuchter (2009) lembra com veemência que uma característica importante do saber dos professores experientes é a de ser situado, ou seja, ancorado nos casos particulares. Segundo a pesquisadora, os professores colocam diversos elementos de saberes e de convicções em rede em torno de casos específicos, e não em torno de elementos teóricos. Apoiando-se nessa ideia, ela evoca as pesquisas que mostram que o saber profissional do professor se transforma em saber de experiência à medida que seu tempo de ensino aumenta (GRUBER, 1999; RUMPF; KRANICH, 2000; TERHART, 2001). É por esse tipo de transformação que o saber disciplinar dos professores passaria, sendo ele uma parte importante do repertório cognitivo dos docentes. No entanto, à medida que o professor atua, a organização dessa bagagem se baseia cada vez mais nas situações e nos casos específicos que reestruturam o saber sistemático em saber situacional (LEUCHTER, 2009). Além disso, os professores se esforçariam para relacionar seus saberes disciplinares aos seus saberes pedagógicos gerais, constituindo assim os conhecimentos 
pedagógicos do conteúdo conceitualizados por Shulman (1987).

Progressivamente, os saberes explícitos se transformam também em saberes tácitos. Os saberes tácitos, que possuem uma influência sobre a reflexão e a ação dos professores, seriam constituídos, por um lado, pela concatenação dos saberes explícitos e, por outro, pelos saberes experienciais, obtidos frequentemente de modo inconsciente pelos indivíduos. Os saberes dos professores se constituiriam, portanto, pela transformação de conhecimentos declarativos em procedimentais, mas também pelas aprendizagens implícitas. Lembremos que uma das características do saber tácito é a sua grande persistência, especialmente no que se refere à fidelidade que os professores têm em relação às suas crenças, modificadas apenas raramente. Outra de suas características é a densidade, ou seja, o fato de que ele contém um grande número de elementos de crenças e de conhecimentos (LEUCHTER, 2009).

Essa transformação do saber explícito em saber experiencial, tácito e procedimental chega, de acordo com Leuchter (2009), a hierarquias de regras de produção. Os saberes procedimentais são usados quando, em dada situação, diversos indícios são considerados pelos professores pedindo que eles sejam aplicados. Podem ser agrupados ou postos em rede para constituir regras de produção superiores por um processo de fragmentação. Esse processo, que facilita a lembrança e a aplicação das regras de comportamento em contextos situacionais, pode ser considerado como uma adensação do saber do professor, que tem como consequência acelerar o ritmo das condutas de ensino e da tomada de decisão (BROMME, 1992). Leuchter (2009) aproxima esse adensamento do saber dos conceitos de script e de esquema, desenvolvidos nas pesquisas do teacher thinking. Para ela, o saber procedimental se manifesta nos comportamentos em ação do professor, mas também faz parte de seu processo de percepção em situação. A emergência do saber procedimental pode ser vista como uma aprendizagem de regras pertinentes para o processo de ensino e que estão ligadas umas às outras. Com a experiência, essas regras se enriquecem progressivamente com elementos específicos das situações de ensino e se tornam, por isso, conjuntos densos de estratégias de análise e de funcionamento que, em ação, permitem uma simplificação da atividade de ensino, assim como uma aceleração do processo de pensamento interativo dos professores (LEUCHTER, 2009).

O saber baseado na experiência terminaria por constituir um sistema de convicções. Fortemente marcadas por aspectos emocionais e lembranças 
pessoais, dificilmente exprimíveis, essas cognições, que podem existir sem comprovação, estão submetidas a um sistema de forças: podemos ser mais ou menos convencidos de sua certeza ou de sua pertinência (THOMPSON, 1992). Elas podem igualmente ser constituídas de elementos contraditórios que os professores equilibram para evoluir na situação de ensino-aprendizagem (BAUMERT; KUNTER, 2006; BORKO; PUTNAM, 1996; CALDERHEAD, 1996; CONNERS, 1978; CORNETT, 1990; FREEMAN, 1991; GASTAGER, 2003; HALKES; DEIJKERS, 2003; HARITOS, 2004; LAMPERT, 1986; LEUCHTER, 2009; MARLAND, 1977; SARDO-BROWN, 1990; SINATRA; KARDASH, 2004; TOMANEK, 1994; WAGNER, 2003; WANLIN; CRAHAY, 2012; WANLIN; LAFONTAINE; CRAHAY, submetido para publicação; WINDSCHITL, 2002; WOOLFOLK HOY et al., 2006; YILDIRIM, 2003). Essas contradições seriam uma das características mais importantes das cognições baseadas na experiência e não perturbariam de maneira nenhuma o agir profissional dos professores (LEUCHTER, 2009). Para a pesquisadora, as cognições de experiência podem ser centrais ou periféricas. Indo ao encontro do que dizem Rokeach (1976) e Richardson (1996), ela considera que as cognições centrais de experiência, tais como os preconceitos, seriam dificilmente modificáveis, sendo até mesmo impossível fazê-las evoluir, pois pôr em questão esse tipo de cognição toca o indivíduo no ponto mais profundo de seu ser. As cognições periféricas teriam, segundo a autora, uma evolução menos dolorosa.

Em resumo, a principal evolução sofrida pelas crenças e pelos conhecimentos dos professores em serviço seria proveniente de sua própria prática. Para os profissionais, não se trataria, na verdade, de mudar as crenças para buscar ideias mais justas, mais validadas, mas sim de buscar crenças cada vez mais “incrustadas” na ação, para tornar a ação do professor cada vez mais adaptada ao contexto de ensino. 


\section{Roles, structuring and evolution of teachers' beliefs (and knowledge)}

Abstract: In summarizing the main contributions of studies about teachers' beliefs and knowledge, this article approaches one of the main issues related to teacher education: do teachers' beliefs and knowledge evolve? In what way? Under what conditions? To answer these questions, we present various research streams: the ones dealing with so-called "natural" change; the ones about the stages in a teacher's development path; studies that examine the effects of teacher education programs; research that evidences team development; and studies about beginner teachers' beliefs. After presenting the existing studies, we discuss our finding, i.e., the challenges facing the evolution of teachers' beliefs, and raise various hypotheses to explain these beliefs' relative imperviousness to educative processes.

Keywords: Knowledge, development of professional capacities, intern teacher, pedagogical practice, teacher education. 


\section{Funciones, estructuración y evolución de las creencias (y conocimientos) de los profesores}

Resumen: Este artículo resume las principales aportaciones de los estudios sobre las creencias y los conocimientos de los profesores, y trata una de las problemáticas vinculadas a la formación docente: ¿las creencias y conocimientos de los profesores evolucionan? ¿De qué manera? ¿En qué condiciones? Para responder a estas preguntas, presentamos diversas corrientes de investigación: las que tratan de los cambios denominados "naturales"; las de las fases de desarrollo del docente; los estudios que verifican los efectos de los programas de formación de profesores; y las investigaciones que evidencian el desarrollo del equipo, además de los estudios sobre las creencias de los profesores principiantes. Después de presentar las investigaciones existentes, discutimos la constatación de la dificultad de la evolución de las creencias de los profesores, planteando varias hipótesis para explicar la impermeabilidad relativa de tales creencias a los procesos formativos.

Palabras clave: Saberes. Desarrollo de capacidades profesionales. Profesor en prácticas. Práctica pedagógica. Formación de profesores. 


\section{REFERÊNCIAS}

ABRIC, J.-C. Les représentations sociales: aspects théoriques. In: Pratiques sociales et représentations. Paris: PUF, 1994. p. 11-36.

AMMON, P. Using case discussions to promote change in beliefs among mathematics teachers. Expertise in teaching from a developmental perspective. The developmental teacher education program at Berkeley. Paper apresentado no Annual Meeting of the American Educational Research Association, Chicago, 1991.

ANDERS, P.; RICHARDSON, V. Research directions: Staff development that empowers teachers' reflection and enhances instruction. Language Arts, v. 68, n. 4, p. 316-321, 1991.

ASHTON, P. Teacher efficacy: A motivational paradigm for effective teacher education. Journal of Teacher Education, v. 35, n. 5, p. 28-32, 1984.

AVIGDOR, R. Étude expérimentale de la genèse des stéréotypes. Cahiers Internationaux de Sociologie, n. 14, p. 154-168, 1953.

BALL, D. Unlearning to teach mathematics. For the Learning of Mathematics, v. 8, n. 1, p. 40-48, 1988.

. Breaking with experience: The role of a preservice methods course.

Paper apresentado no Annual Meeting of the American Educational Research Association, San Francisco, 1989. Disponível em: 〈http://ncrtl.msu.edu/http/ ipapers/html/pdf/ip8910.pdf . Acesso em: 26 out. 2010.

BALL, S.; GOODSON, I. Understanding teachers: concepts and contexts. In: ; _______. Teachers' lives and careers. Londres: Falmer Press, 1985.

p. 1-26.

BANDURA, A. Social foundations of thought and action: A social cognitive theory. Englewood Cliffs: Prentice-Hall, 1986.

BARNETT, C.; SATHER, S. Using case discussions to promote change in beliefs among mathematics teachers. Paper apresentado no Annual Meeting of the American Educational Research Association, San Francisco, 1992.

BAUMERT, J.; KUNTER, M. Stichwort: Professionelle Kompetenz von Lehrkräften. Zeitschrift für Erziehungswissenschaft, n. 4, p. 469-520, 2006. 
BERLINER, D. Expertise: The wonder of exemplary performances. In: MANGIERE, J.; BLOCK, C. Creating powerful thinking in teachers and students: Diverse perspectives. Fort Worth: Harcourt Brace College, 1994. p. 161-186.

BLACK, A.; AMMON, P. A developmental-constructivist approach to teacher education. Journal of Teacher Education, v. 43, n. 5, p. 323-335, 1992.

BLUMENFELD, P.; KRACJIK, J.; MARX, R.; SOLOWAY, E. Lessons learned: How collaboration helped middle-grade science teachers learn project-based instruction. Elementary School Journal, v. 94, n. 5, p. 539-551, 1994.

BOLIN, F. Helping student teachers think about teaching: Another look at Lou. Journal of Teacher Education, v. 41, n. 1, p. 10-19, 1990.

BOOK, C.; FREEMAN, D. Differences in entry characteristics of elementary and secondary teacher candidates. Journal of Teacher Education, v. 37, n. 2, p. 47$51,1986$.

; BYERS, J.; FREEMAN, D. Student expectations and teacher education traditions with which we can and cannot live. Journal of Teacher Education, v. 34, n. 1, p. 1-13, 1983.

BORKO, H.; PUTNAM, R. Learning to teach. In: BERLINER, D.; CALFEE, R. Handbook of educational psychology. Nova York: MacMillan, 1996. p. 673708.

; SHAVELSON, R. Teacher decision making. In: JONES, B.; IDOL, L. Dimensions of thinking and cognitive instruction. New Jersey: Erlbaum, 1990. p. 311-346.

BOS, C.; ANDERS, P. The study of student change. In: RICHARDSON, V. Teacher change and the staff development process. Nova York: Teachers College Press, 1994, p. 181-198.

BROMME, R. Des Lehrer als Experte: Zur Psychologie des professionellen Wissens. Berna: Hans Huber, 1992.

BRONFENBRENNER, U. Ecology of the family as a context for human development: Research perspectives. Developmental Psychology, v. 22, n. 6, p. 723-742, 1986.

BROOKHART, S.; FREEMAN, D. Characteristics of entering teacher candidates. Review of Educational Research, v. 62, n. 1, p. 37-60, 1992. 
BROUDY, H. What do professors of education profess? The Educational Forum, v. 44, n. 4, p. 441-451, 1980.

BUCHMANN, M. Role over person: legitimacy and authenticity in teaching. In: BEN PERETZ, M.; BROMME, R.; HALKES, R. Advances of research on teacher thinking. Lisse: Swets \& Zeitlinger B.V., 1986. p. 55-69.

- Role over person: Justifying teacher action and decisions. Scandinavian Journal of Educational Research, v. 31, n. 1, p. 1-21, 1987.

BULLOUGH, R. First-year teaching: A case study. Teachers College Record, v. 89, n. 2, p. 219-237, 1987.

; BAUGHMAN, K. First-year teacher. Eight years later: An inquiry into teacher development. Nova York: Teachers College Press, 1997.

; KNOWLES, J. Becoming a teacher: Struggles of a second-career beginning teacher. International Journal for Qualitative Studies in Education, v. 3, n. 2, p. 101-112, 1990.

; KNOWLES, J. Teaching and nurturing: Changing conceptions of self as teacher in a case study of becoming a teacher. Qualitative Studies in Education, v. 4, n. 2, p. 121-140, 1991.

BUTT, R.; RAYMOND, D.; McCUE, G.; YAMAGISI, L. Collaborative autobiography and the teacher's voice. In: GOODSON, I. Studying teachers' lives. Nova York: Teachers College Press, 1992. p. 51-98.

CALDERHEAD, J. The contribution of field experiences to student primary teachers' professional learning. Research in Education, n. 40, p. 34-49, 1988.

- Teachers: Beliefs and knowledge. In: BERLINER, D.; CALFEE, R. Handbook of educational psychology. Nova York: MacMillan, 1996. p. 673708.

; ROBSON, M. Images of teaching: Student teachers' early conceptions of classroom practice. Teaching \& Teacher Education, v. 7, n. 1, p. 1-8, 1991.

CARPENTER, T.; FENNEMA, E.; PETERSON, P.; CHIANG, C.; LOEF, M. Using knowledge of children's mathematics thinking in classroom teaching: An experimental study. American Educational Research Journal, v. 26, n. 4, p. 499-531, 1989.

CHIN, R.; BENNE, K. General strategies for effecting changes in human systems. 
In: BENNIS, W.; BENNE, K.; CHIN, R. The planning of change. 2. ed. Nova York: Holt, Rinehart \& Winston, 1969. p. 32-59.

CIVIL, M. Prospective elementary teachers' thinking about teaching mathematics Journal of Mathematical Behavior, v. 12, n. 1, p. 79-109, 1993. . Listening to students' ideas: Teachers interviewing in mathematics. In: MEIRA, L.; CARAHER, D. Proceedings of the 19th Psychology of mathematics education conference. v. 2. Recife: Universidade Federal de Pernambuco, 1995, p. 154-161.

- Thinking about mathematics and its teaching: An experience with preservice teachers. In: GIMENEZ, J.; LLINARES, S.; SANCHEZ, V. Becoming a primary teacher: Issues from mathematics education. Badajoz: Autores, 1996, p. 137-154.

CLARK, C.; PETERSON, P. Teachers' thought processes. In: WITTROCK, M. Handbook of research on teaching. 3. ed. Nova York: MacMillan, 1986. p. 255296.

COCHRAN-SMITH, M. Learning to teach against the grain. Harvard Educational Review, v. 61, n. 3, p. 279-310, 1991.

COHEN, D. A revolution in one classroom: The case of Mrs Oublier. Educational Evaluation and Policy Analysis, v. 12, n. 3, p. 311-344, 1990.

COMEAUX, M. Challenging students' views about teaching and learning: Constructivism in social foundations classroom. Paper apresentado no Annual Meeting of the American Educational Research Association, San Francisco, 1992.

CONNERS, R. An analysis of teacher thought processes, beliefs, and principles during instruction. 1978. Tese (Doutorado em Ciências da Educação)University of Alberta, Edmonton, Canadá, 1978.

CORNETT, J. Teacher thinking about curriculum and instruction: A case study of a secondary social studies teacher. Theory and Research in Social Education, v. 18 , n. 3, p. 248-273, 1990.

CRAHAY, M. Contraintes de situation et interactions maître-élève: changer sa façon d'enseigner, est-ce possible? Revue Française de Pédagogie, n. 88, p. 67-94, 1989. 
. L'école peut-elle être juste et efficace? De l'égalité des chances à l'égalité des acquis. Bruxelas: De Boeck, 2000.

Peut-on conclure à propos des effets du redoublement? Revue Française de Pédagogie, n. 148, p. 11-23, 2004.

. Peut-on lutter contre l'échec scolaire? 3. ed. Bruxelas: De Boeck, 2006.

; DONNAY, J. La mise en place de la réforme du premier degré de l'enseignement secondaire. Recherche interuniversitaire, Rapport de recherche auprès du ministre de l’Enseignement secondaire, Université de Liège, 2001.

; FAGNANT, A. À propos de l'épistémologie personnelle: un état des recherches anglo-saxonnes. Revue Française de Pédagogie, n. 161, p. 79-117, 2008.

; MONSEUR, C. Différences individuelles et effets d'agrégation en ce qui concerne les performances en lecture. Analyse secondaire des données PISA 2000. In: HOUSSEMAND, C.; MARTIN, R.; DICKES, P. Perspectives de psychologie différentielle. Rennes: Presses Universitaires de Rennes, 2006. p. 23-34.

; ORY, P. Les représentations des normaliens en matière de redoublement évoluent-elles au cours de leur formation à l'école normale? Paper apresentado no 4e Congrès des Chercheurs en Éducation, Bruxelas, 2006.

CRONIN-JONES, L. Science teacher beliefs and their influence on curriculum implementation: Two case studies. Journal of Research in Science Teaching, v. 28, n. 3, p. 235-250, 1991.

CUBAN, L. How Teachers Taught: Constancy and Change in American Classrooms, 1890-1980. Nova York: Longman, 1984.

. Constancy and change in schools (1880s to the present). In: JACKSON, P. Contributing to educational change: Perspectives on research and practice. Berkeley: McCutcheon, 1988. p. 85-106.

DE LANDSHEERE, G. Dictionnaire de l'évaluation et de la recherche en éducation. Paris: PUF, 1979.

DEWEY, J. How we think: A restatement of the relation of reflective thinking to 
the educative process. Boston: D. C. Heath, 1933.

DIEDRICH, M.; THUSSBAS, C.; KLIEME, E. Professionnelles Lehrerwissen uns selbstberichte Unterrichtspraxis im Fach Mathematik. Zeitschrift für Pädagogik, n. 45 [Beiheft], p. 107-123, 2002.

DOISE, W. Relations et representations intergroupes. In: MOSCOVICl, S. Introduction à la psychologie sociale. Paris: Larousse, 1973. v. 2.

DOUDIN, P.-A.; PFULG, L.; MARTIN, D.; MOREAU, J. Entre renoncement et engagement. Un défi pour la formation continuée des enseignants. In: LAFORTUNE, L.; DEAUDELIN, C.; DOUDIN, P.-A.; MARTIN, D. La formation continue. De la réflexion à l'action. Québec: Presses de l'Université du Québec, 2001.

DOYLE, W. Paradigms for research on teacher effectiveness. Paper apresentado no Annual Meeting of the American Educational Research Association, Washington, 1975.

. Paradigms for research on teacher effectiveness. Review of Research in Education, v. 5, n. 1, p. 163-198, 1977.

. Making managerial decisions in classrooms. In: DUKE, D. Classroom management: The 78th yearbook of the National Society for the Study of Education. Chicago: University of Chicago Press, 1979. p. 42-74.

Classroom organisation and management. In: WITTROCK, $M$. Handbook of research on teaching. 3. ed. Nova York: MacMillan, 1986. p. 392431.

; PONDER, G. The practicality ethic in teacher decision-making. Interchange, v. 8, n. 3, p. 1-12, 1977.

DRAELANTS, H. Le redoublement est moins un problème qu'une solution: comprendre l'attachement social au redoublement en Belgique francophone. Les Cahiers de Recherche en Éducation et Formation, n. 52, p. 3-21, 2006.

. Réforme pédagogique et légitimation. Le cas d'une politique de lutte contre le redoublement. Bruxelas: De Boeck, 2009.

DUFFY, G.; ROEHLER, L. Constraints on teacher change. Journal of Teacher Education, v. 35, p. 55-58, 1986.

EVERTSON, C.; WEINSTEIN, C. Classroom management as a field of inquiry. In: 
; Handbook of classroom management: Research, practice, and contemporary issues. Mahwah: Lawrence Erlbaum, 2006. p. 3-16.

FEIMAN-NEMSER, S. Learning to teach. In: SHULMAN, L.; SYKES, G. Handbook of teaching and policy. Nova York: Longman, 1983. p. 150-171.

- Teacher preparation: Structural and conceptual alternatives. In: HOUSTON, R. Handbook of research on teacher education. Nova York: McMillan, 1990. p. 212-233.

; BUCHMANN, M. Describing teacher education: A framework and illustrative findings from a longitudinal study of six students. The Elementary School Journal, v. 89, n. 3, p. 365-377, 1989.

; MCDIARMID, G.; MELNICK, S.; PARKER, M. Changing beginning teachers' conceptions: A description of an introductory teacher education course. East Lansing: National Center for Research on Teacher Education, College of Education, Michigan State University, 1989.

FENNEMA, E.; CARPENTER, T.; FRANKE, M.; CAREY, D. Learning to use children's mathematical thinking: A case study. In: R. DAVIS, R.; MAHER, C. Schools, mathematics and the world of reality. Needham Heights: Allyn \& Bacon, 1992. p. 93-117.

FENSTERMACHER, G. A philosophical consideration of recent research on teacher effectiveness. Review of Research in Education, v. 6, n. 1, p. 157-185, 1979.

. How should implications of research on teaching be used? Elementary School Journal, v. 83, n. 4, p. 496-499, 1983.

. On getting from here (research) to there (practice). In: EGBERT, R.; KLUENDER, M. Using research to improve teacher education. Washington: Clearinghouse, 1984a. p. 22-27.

What counts as research on teacher education? In: HORD, S.; O'NEAL, S.; SMITH, M. Beyond the looking glass: Papers from a national symposium on teacher education policies, practices \& research. Austin: University of Texas at Austin, 1984b. p. 27-33.

Who decides the worth of educational research? In: ROBERTSON, E. Philosophy of education, 1984. Proceedings of the fortieth Annual Meeting of the Philosophy of Education Society. Normal: Philosophy of Education Society, 
1985. p. 295-298.

. Philosophy of research on teaching: Three aspects. In: WITTROCK, M. Handbook of research on teaching. 3. ed. Nova York: MacMillan, 1986. p. 37-49.

. The knower and the known: The nature of knowledge in research on teaching. Review of Research in Education, v. 20, n. 1, p. 3-56, 1994.

FLODEN, R.; CLARK, C. Preparing teachers for uncertainty. Teacher College Record, v. 89, n. 4, p. 505-524, 1988.

FREEMAN, D. To make the tacite explicite: Teacher education, emerging discourse, and conceptions of teaching. Teaching and Teacher Education, v. 9, n. 5-6, p. 439-454, 1991.

- Renaming experience/reconstructing practice: Developing new understandings of teaching. Teaching and Teacher Education, v. 9, n. 5-6, p. 485-497, 1993.

FULLAN, M. Staff development, innovation and institutional development. In: JOYCE, B. Changing school culture through staff development. Alexandria: Association for Supervision and Curriculum Development, 1990. p. 3-25.

. The new meaning of educational change. 2. ed. Nova York: Teachers College Press, 1991.

FULLER, F. Concerns of teachers: A developmental conceptualization. American Educational Research Journal, v. 6, n. 2, p. 207-226, 1969.

; BOWN, O. Becoming a teacher. In: RYAN, K. The 74th yearbook of the National Society for the Study of Education, part 2. Chicago: University of Chicago Press, 1975. p. 25-52.

GAGE, N.-G. Comment tirer un meilleur parti des recherches sur les processus d'enseignement. In: CRAHAY, M.; LAFONTAINE, D. L'art et la science de l'enseignement. Bruxelas: Labor, 1986.

GASTAGER, A. Paradigmenvielfalt aus Sicht des Unterrichtenden. Lengerich: Pabst, 2003.

GRANT, C. Teacher capacity. In: COCHRAN-SMITH, M.; FEIMAN-NEMSER, S.; MCINTYRE, D.; DEMERS, K. Handbook of research on teacher education. 3. ed. Nova York: Routledge, 2008. p. 127-133. 
; AGOSTO, V. Teacher capacity and social justice in teacher education. In: COCHRAN-SMITH, M.; FEIMAN-NEMSER, S.; MCINTYRE, D.; DEMERS, K. Handbook of research on teacher education. 3. ed. Nova York: Routledge, 2008. p. 175-200.

GREEN, T. The activities of teaching. Nova York: McGraw-Hill, 1971.

GRUBER, H. Erfahrung als Grundlage kompetenten Handelns. Berna: Huber, 1999.

GURNEY, B. Tugboats and tennis games: Pre-service conception of teaching and learning revealed through metaphors. Journal of Research in Science Teaching, v. 32, n. 6, p. 569-583, 1995.

GUSKEY, T. Staff development and the process of teacher change. Educational Researcher, v. 15, n. 5, p. 5-12, 1986.

HALKES, R.; DEIJKERS, R. Teachers' teaching criteria. In: KOMPF, M.; DENICOLO, P. Teacher thinking twenty years on: Revisiting persisting problems and advances in education. Lisse: Swets \& Zeitlinger B.V., 2003, p. 3-13.

HANCOCK, E.; GALLARD, A. Preservice science teachers' beliefs about teaching and learning: The influence of $\mathrm{K}-12$ field experiences. Journal of Science Teacher Education, v. 15, n. 4, p. 281-291, 2004.

HARINGTON, H.; HATHAWAY, R. Computer conferencing, critical reflection, and teacher development. Teaching and Teacher Education, v. 10, n. 2, p. 543-554, 1994.

HARITOS, C. Understanding teaching through the minds of teacher candidates: A curious blend of realism and idealism. Teaching and Teacher Education, v. 20, n. 6, p. 637-654, 2004.

HAUSOUL, E. Quels sont les effets de l'insertion professionnelle des enseignants sur leurs représentations sociales et, plus précisément, sur leur représentation de l'échec scolaire? Mémoire de licence en sciences de l'éducation non publié, Université de Liège, Liège, 2005.

HOBAN, G. Reflection on what? Assisting teachers to frame and reframe their practice. Paper apresentado no Annual Meeting of the American Educational Research Association, San Francisco, 1995.

HOFER, B.; PINTRICH, P. The development of epistemological theories: Beliefs 
about knowledge and knowing and their relation to learning. Review of Educational Research, v. 67, n. 1, p. 88-140, 1997.

HOLLINGSWORTH, S. Prior beliefs and cognitive change in learning to teach. American Educational Research Journal, v. 26, n. 2, p. 160-189, 1989.

HOLT-REYNOLDS, D. Personal history-based beliefs as relevant prior knowledge in course work. American Educational Research Journal, v. 29, n. 2, p. 325-349, 1992.

HOWARD, T.; ALEMAN, G. Teacher capacity for diverse learners. What do teacher need to know? In: COCHRAN-SMITH, M.; FEIMAN-NEMSER, S.; MCINTYRE, D.; DEMERS, K. Handbook of research on teacher education. 3. ed. Nova York: Routledge, 2008. p. 157-174.

HOY, W. Organizational socialization: The student teacher and pupil control ideology. The Journal of Educational Research, v. 61, n. 4, p. 153-259, 1967.

; WOOLFOLK, A. Socialization of student teachers. American Educational Research Journal, v. 27, n. 2, p. 279-300, 1990.

HUBER, G.; ROTH, J. Teachers' classroom activities and certainty and incertainty orientation. In: DAY, A. Insight into teachers' thinking and action. Londres: Falmer Press, 1990, p. 119-132.

HUBERMAN, M. On teachers' careers: Once over lightly with a broad brush. International Journal of Educational Research, v. 13, n. 4, p. 347-361, 1989.

HUBERMAN, A.; GROWNVER, M.; MARTIN, J. La vie des enseignants. Neuchâtel: Delachaux et Niestlé, 1989. [Tradução inglesa em 1993: The lives of teachers. London: Cassell].

ISSAIEVA, E.; CRAHAY, M. Conceptions de l'évaluation scolaire des élèves et des enseignants: validation d'échelles et étude de leurs relations. Mesure et Évaluation en Éducation, v. 33, n. 1, p. 31-62, 2010.

JENSEN, J. Teacher candidates' conceptions of teaching and learning: A review. Paper apresentado no Annual Meeting of the American Educational Research Association, San Diego, 1998.

JONES, M.; VESILIND, E. Putting practice into theory: Changes in the organization of preservice teachers' pedagogical knowledge. American Educational Research Journal, v. 33, n. 1, p. 91-117, 1996. 
KAGAN, D. Implications of research on teacher beliefs. Educational Psychologist, v. 27, n. 1, p. 65-90, 1992.

KIRSCHNER, P.; SWELLER, J.; CLARK, R. Why minimal guidance during instruction does not work: An analyis of the failure of constructivist, discovery, problembased, experiential, and inquiry-based teaching. Educational Psychologist, v. 41, n. 2, p. 75-86, 2006.

KLIEME, E.; REUSSER, K. Unterrichtsqualität und mathematisches Verständnis im internationalen Vergleich? Ein Forschungsprojekt und erste Schritte zur Realisierung. Unterrichtswissenschaft, v. 31, n. 3, p. 194-205, 2003.

KNOWLES, J. Models for teachers' biographies. In: GOODSON, I. Studying teachers' lives. Nova York: Teachers College Press, 1992. p. 99-152.

KORTHAGEN, F. The influence of learning orientations on the development of reflective teaching. In: CALDERHEAD, J. Teachers' Professional Learning. Filadélfia: Falmer Press, 1988. p. 35-50.

KRAJCIK, J.; LAYMAN, J.; STARR, M.; MAGNUSSON, S. The development of middle school teachers' content knowledge and pedagogical content knowledge of heat energy and temperature. Paper apresentado no Annual Meeting of the American Educational Research Association, Chicago, 1991.

KREMER, L. Personal characteristics of teachers, situational variables and deliberations in the process of planning instruction. Research in Education, $n$. 26, p. 21-30, 1981.

LAKOFF, G.; JOHNSON, M. Les métaphores dans la vie quotidienne. Tradução M. de Fornel e J.-J. Lecercle. Paris: Éd. de Minuit, 1985.

LALANDE, A. Vocabulaire technique et critique de la philosophie. Paris: PUF, 2002.

LAMPERT, M. Teachers' strategies for understanding and managing classroom dilemmas. In: BEN PERETZ, M.; BROMME, R.; HALKES, R. Advances of research on teacher thinking. Lisse: Swets \& Zeitlinger B.V., 1986. p. 70-83.

LANIER, J.; LITTLE J. Research on teacher education. In: WITTROCK, M. Handbook of research on teaching. 3. ed. Nova York: MacMillan, 1986. p. 527-569.

LEAVY, A.; McSORLEY, F.; BOTÉ, L. An examination of what metaphor construction reveals about the evolution of preservice teachers' beliefs about 
teaching and learning. Teaching and Teacher Education, v. 23, n. 7, p. 12171233, 2007.

LESTER, N.; ONORE, C. Learning change. Portsmouth: Boynton/Cook, 1990.

LEUCHTER, M. Die Rolle der Lehrperson bei der Aufgabenbearbeeitung: Unterrichtsbezogene Kognitionen von Lehrpersonen. Münster: Waxmann, 2009.

; REUSSER, K.; PAULI, C.; KLIEME, E. Zusammenhänge zwischen unterrichtsbezogenen Kognitionen und Handlungen von Lehrpersonen. In: GLÄSER-ZIKUDA, M.; SEIFRIED, J. Lehrerexpertise. Analyse und Bedeutung unterrichtlichen Handelns. Münster: Waxmann, 2008. p. 165-186.

LEVIN, B.; AMMON, P. The development of the beginning teachers' pedagogical thinking: A longitudinal analysis of four case studies. Teacher Education Quarterly, v. 19, n. 4, p. 19-37, 1992.

LIEBERMAN, A. Introduction: The changing contexts of teaching. In:

The changing contexts of teaching. Ninety first yearbook of the National society for the study of education. Chicago: University of Chicago Press, 1992, p. 1-10.

LINDBLAD, S. From technology to craft: On teachers' experimental adoption of technology as a new subject in the Swedish primary school. Journal of Curriculum Studies, v. 22, n. 2, p. 165-175, 1990.

LIPOWSKY, F. Auf den Lehrer kommt es an. Empirische Evidenzen für Zusammenhänge zwischen Lehrerkompetenzen, Lehrerhandeln und dem Lernen der Schüler. Zeitschrift für Pädagogik, n. 51 [Beiheft], p. 47-70, 2006.

LISTON, D.; ZEICHNER, K. Action research and reflective teaching in preservice teacher education. Paper apresentado no Annual Meeting of the American Educational Research Association, San Francisco, 1989.

LORD, C.; ROSS, L.; LEPPER, M. Biased assimilation and attitude polarization: the effects of prior theories on subsequently considered evidence. Journal of Personality and Social Psychology, v. 37, n. 11, p. 2098-2109, 1979.

LORTIE, D. Schoolteacher. Chicago: University of Chicago Press, 1975.

LOUDEN, W. Understanding teaching: Continuity and change in teacher's knowledge. Nova York: Teachers College Press, 1991.

MAHLIOS, M.; MAXSON, M. Metaphors as structures for elementary and 
secondary preservice teachers' thinking. International Journal of Educational Research, v. 29, n. 3, p. 227-240, 1998.

MARCOUX, G.; CRAHAY, M. Mais pourquoi continuent-ils à faire redoubler? Essai de compréhension du jugement des enseignants. Revue des Sciences de l'Éducation, v. 30, n. 3, p. 501-518, 2008.

MARKES, S. Acquiring pratical knowledge: A study of development through observations of student teaching practice and dialogues of community. 1995. Tese (Doutorado em Ciências da Educação)-University of Arizona, Tucson, 1995.

MARKS, S.; GERSTEN, R. Engagement and disengagement between special and general educators: An application of Miles and Huberman's cross-case analysis. Learning Disabilities Quarterly, v. 21, n. 1, p. 34-56, 1998.

MARLAND, P. A study of teachers' interactive thoughts. 1977. Tese (Doutorado e, Ciências da Educação)-University of Alberta, Edmonton, Canadá, 1977.

Teachers' knowledge of students: A significant domain of practical knowledge? 1993. Disponível em: 〈http://www.aare.edu.au/93pap/ marlp93147.txt>. Acesso em: 26 out. 2010.

MARTINET, C.; RIEBEN, L. L'apprentissage initial de la lecture et ses difficultés. In : M. CRAHAY, M.; DUTRÉVIS, M. Psychologie des apprentissages scolaires. Bruxelas: De Boeck, 2010. p. 189-224.

MAYER D.; MARLAND P. Teachers' knowledge of students: A significant domain of practical knowledge? Asia-Pacific Journal of Teacher Education, v. 25, n. 1, p. 17-34, 1997.

MCDIARMID, G. Challenging prospective teachers' beliefs in an early field experience: A quixotic undertaking? Journal of Teacher Education, v. 29, n. 1, p. 21-29, 1990.

- What to do about differences? A study of multicultural education for teacher trainees in the Los Angeles unified school district. Journal of Teacher Education, v. 43, n. 2, p. 83-93, 1992.

; CLEVENGER-BRIGHT, M. Rethinking teacher capacity. In: COCHRANSMITH, M.; S. FEIMAN-NEMSER, S.; MCINTYRE, D.; DEMERS, K. Handbook of research on teacher education. 3. ed. Nova York: Routledge, 2008, p. 134-156. 
MCDONALD, J. Raising the teacher's voice and the ironic role of theory. Harvard Educational Review, v. 56, n. 4, p. 355-378, 1986.

MCLAUGHLIN, M. Learning from experience: Lessons from policy implementation. Educational Evaluation and Policy Analysis, v. 9, n. 2, p. 171178, 1994.

MELLADO, V. The classroom practice of preservice teachers and their conceptions of teaching and learning science. Science Education, v. 82, n. 2, p. 197-214, 1998.

MEVARECH, Z. Teachers' paths on the way to and from the professional development forum. In: GUSKEY, T.; HUBERMAN, M. Professional development in education: New paradigms and practices. Nova York: Teachers College Press, 1995. p. 151-170.

MONSEUR, C.; CRAHAY, M. Composition académique et sociale des établissements, efficacité et inégalités scolaires: une comparaison internationale. Revue Française de Pédagogie, n. 162, p. 55-65, 2008.

MONTGOMERY, C.; LEGAULT, F.; GAUTHIER, C.; BUJOLD, N. Conceptions of an efficient teacher, motivations of career choice, and feelings of efficacy in secondary school student teachers. Res Academica, v. 17, n. 1, p. 139-163, 1999.

MUGNY, G.; CARUGATI, F. L'intelligence au pluriel. Les représentations sociales de l'intelligence et de son développement. Cousset: Delval, 1985.

MUNBY, $\mathrm{H}$. The place of the teachers' beliefs in research on teacher thinking and decision making and alternative methodology. Instructional Science, v. 11, n. 3, p. 201-225, 1982.

A qualitative study of teachers' beliefs and principles. Paper apresentado no Annual Meeting of the American Educational Research Association, Montréal, Canadá, 1983.

; RUSSELL, T. Transforming chemistry research into chemistry teaching: The complexities of adopting new frames for experience. In: RUSSELL, T.; MUNBY, $\mathrm{H}$. Teachers and teaching: From classroom to reflection. Londres: Falmer Press, 1992. p. 90-123.

; RUSSELL, T. The authority of experience in learning to teach: Messages from a physics methods class. Journal of Teacher Education, v. 45, 
n. 2, p. 86-95, 1994.

; CUNNINGHAM, M.; CHIN, P. Co-operative education: The functions of experience in workplace learning. Paper apresentado no Annual Meeting of the Canadian Society for Studies in Education, Ottawa, Canadá, 1998.

; RUSSELL, T.; MARTIN, A. Teachers' knowledge and how it develops. In: RICHARDSON, V. Handbook of research on technopole. Washington: American Educational Research Association, 2001. p. 877-904.

MUNRO, R. A case study of school-based training systems in New Zealand secondary schools. In: ELLIOTT, J. Reconstructing Teacher Education. Londres: Falmer Press, 1993. p. 95-109.

NAULT, T. L'enseignant et la gestion de la classe. Montréal: Éd. Logiques, 1999.

NESPOR, J. The role of beliefs in the practice of teaching. Journal of Curriculum Studies, v. 19, n. 4, p. 317-328, 1987.

NIAS, J. Teaching and the self. In: HOLLY, M.; MCLOUGHLIN, C. Perspectives on teacher professional development. Londres: Falmer Press, 1989. p. 155-172.

NISBETT, R.; ROSS, L. Human inference: Strategies and shortcomings of social judgment. Englewood Cliffs: Prentice-Hall, 1980.

OLSON, J. Teacher constructs and curriculum change. Journal of Curriculum Studies, v. 1, n. 1, p. 1-11, 1980.

Teacher influence in the classroom. A context for understanding curriculum translation. Instructional Science, v. 10, n. 3, p. 259-275, 1981.

OLSON, M. Knowing what counts in teacher education. Paper apresentado na Canadian Association of Teacher Educators, Canadian Society of Studies in Education, Ottawa, Canadá, 1993.

OPDENAKKER, M.; VAN DAMME, J. Teacher characteristics and teaching styles as effectiveness enhancing factors of classroom practice. Teaching and Teacher Education, v. 22, n. 1, p. 1-21, 2006.

PAJARES, F. Teachers' beliefs and educational research: Cleaning up a messy construct. Review of Educational Research, v. 62, n. 3, p. 307-332, 1992.

PALINSCAR, A.; MAGNUSSON, S.; MARANO, N.; FORD, D.; BROWN, N. Designing a community of practice: Principles and practices of the GIsML community. 
Teaching and Teacher Education, v. 14, n. 1, p. 5-19, 1998.

PETERSON, P.; FENNEMA, E.; CARPENTER, T.; LOEF, M. Teachers' pedagogical content beliefs in mathematics. Cognition and Instruction, v. 6, n. 1, p. 1-40, 1989.

PHILIP, R.; ARMSTRONG, B.; BEZUK, N. A preservice teacher learning to teach mathematics in a cognitively guided manner. In: BECKER, J.; PENCE, B. Proceedings of the fifteenth annual meeting of the PME-NA, v. 2. Pacific Grove: San Jose State University, 1993. p. 159-165.

PIAGET, J. L'équilibration des structures cognitives: problème central du développement. Paris: PUF, 1975.

PINES, A.; WEST, L. Conceptual understanding and science learning: An interpretation of research within a sources-of-knowledge framework. Science Education, v. 70, n. 5, p. 583-604, 1986.

PLACIER, P.; HAMILTON, M. Schools as contexts: A complex relationship. In: RICHARDSON, V. Teacher change and the staff development process: A case in reading instruction. Nova York: Teachers College Press, 1994. p. 135-159.

PRAWATT, R. Are changes in views about mathematics teaching sufficient? The case of a fifth-grade teacher. The Elementary School Journal, v. 93, n. 2, p. 195-211, 1992.

REMILLARD, J. Examining key concepts in research on teachers' use of mathematics curricula. Review of Educational Research, v. 75, n. 2, p. 211246, 2005.

RICHARDSON, V. Significant and worthwhile change in teaching practice. Educational Researcher, v. 19, n. 7, p. 10-18, 1990.

. The consideration of beliefs in staff development. In: Teacher change and the staff development process: A case of reading instruction. Nova York: Teachers College Press, 1994. p. 90-108.

. The role of attitudes and beliefs in learning to teach. In: SIKULA, J. Handbook of Research on Teacher Education. Nova York: MacMillan, 1996. p. 102-119.

. Professional development in the instruction of reading. In: OSBORN, J.; LEHR, F. Literacy for all: Issues in teaching and learning. Chicago: Guilford 
Press, 1998. p. 303-318.

; HAMILTON, M. The practical argument staff development process. In: . Teacher change and staff development process: A case in reading instruction. Nova York: Teachers College Press, 1994, p. 109-134.

; PLACIER, P. Teacher change. In: . Handbook of research on teaching. Washington: American Educational Research Association, 2001. p. 905-947.

; ANDERS, P.; TIDWELL, D.; LLOYD C. The relationship between teachers' beliefs and practices in reading comprehension instruction. American Educational Research Journal, v. 28, n. 3, p. 559-586, 1991.

RICHARDSON-KOEHLER, V. Barriers to the effective supervision of student teaching: A field study. Journal of Teacher Education, v. 39, n. 2, p. 28-34, 1988.

ROKEACH, M. Beliefs, attitudes and values: A theory of organization and change. San Francisco: Jossey-Bass, 1976.

ROSS, D.; JOHNSON, M.; SMITH, W. Developing a professional teacher at the University of Florida. Paper apresentado no Annual Meeting of the American Educational Research Association, Chicago, 1991.

ROZENHOLTZ. Teachers' workplace: The social organization of schools. Nova York: Longman, 1989.

RUMPF, H.; KRANICH, E. Welche Art von Wissen braucht des Lehrer? Ein Einspruch gegen landläufige Praxis. Stuttgart: Klett, 2000.

RUSSELL, T. From pre-service teacher education to first year of teaching: A study of theory and practice. In: CALDERHEAD, J. Teachers' professional learning. Londres: Falmer Press, 1988. p. 13-34.

. A teacher educator and his students reflect on teaching high school physics. Teacher Education Quarterly, v. 22, n. 3, p. 85-98, 1995.

; MUNBY, H.; SPAFFORD, C.; JONSTHON, P. Learning the professional knowledge of teaching. In: GRIMMENT, P.; ERICKSON, G. Reflection in teacher education. Nova York: Teachers College Press, 1988. p. 67-90.

RYAN, K. Lives of first year teachers. Paper apresentado no Annual Meeting of the American Association of Teacher Educators, Washington, 1986. 
SABAN, A.; KOCBEKER, B.; SABAN, A. Prospective teachers' conceptions of teaching and learning revealed through metaphor analysis. Learning and Instruction, v. 17, n. 2, p. 123-139, 2007.

SARDO-BROWN, D. Experienced teachers' planning practices: A US survey. Journal of Education for Teaching, v. 16, n. 1, p. 57-71, 1990.

SAUSSEZ, F.; LESSARD, C. Entre orthodoxie et pluralisme, les enjeux de l'éducation basée sur la preuve. Revue Française de Pédagogie, n. 168, p. 111136, 2009.

SCHIFTER, D. Teachers' changing conceptions of the nature of mathematics: Enactment in the classroom. In: NELSON, B. Inquiry and the development of teaching: Issues in the transformation of mathematics teaching. Newton: Center for the Development of Teaching, 1995. p. 17-25.

SCHMIDT, W.; KENNEDY, M. Teachers' and teacher candidates' beliefs about subject matter and about teaching responsibilities. Research report. 1990. East Lansing: Michigan State University. Disponível em: 〈http://www.eric. ed.gov/PDFS/ED320902.pdf〉. Acesso em: 28 set. 2010.

SCHOMMER, M. Effects of beliefs about the nature of knowledge on comprehension. Journal of Educational Psychology, v. 82, n. 3, p. 498-504, 1990.

SCHÖN, D. Le praticien réflexif. Montréal: Éd. Logiques, 1994.

SHULMAN, L. Knowledge and teaching: foundations of the new reform. Harvard Educational Review, v. 57, n. 1, p. 1-22, 1987.

SIEGLER, R. Intelligences et développement de l'enfant. Variations, évolution, modalités. Bruxelas: De Boeck, 1999.

SIGEL, I. A conceptual analysis of beliefs. In: SIGEL, I. Parental beliefsystems: The psychological consequences for children. Hillsdale: Erlbaum, 1985. p. 345-371.

SIMON, M.; MAZZA, W. From learning mathematics to teaching mathematics: A case study of a prospective teacher in a reform-oriented program. Paper apresentado no Annual Meeting of the North American Chapter of the International Group for the Psychology of Mathematics Education, Monterey, 1993. 
SINATRA, G.; KARDASH, C. Teacher candidates' epistemological beliefs, dispositions, and views on teaching as persuasion. Contemporary Educational Psychology, v. 29, n. 4, p. 483-489, 2004.

SMITH, D.; NEALE, D. The construction of subject matter knowledge in primary science teaching. Teaching and Teacher Education, v. 5, n. 1, p. 1-20, 1989.

SPARKS, G. Teachers' attitude toward change and subsequent improvements in classroom teaching. Journal of Educational Psychology, v. 80, n. 1, p. 111117, 1988.

SPARKS, G.; LOUCKS-HORSLEY, S. Models of staff development. In: HOUSTON, W. Handbook of Research on Teacher Education. Nova York: MacMillan, 1990. p. 234-250.

STALLINGS, J. School achievement effects and staff development: What are some critical factors? Paper apresentado no Annual Meeting of the American Educational Research Association, San Francisco, 1989.

; KRASAVAGE, E. Program implementation and student achievement in a four-year Madeleine Hunter Follow-Through project. Elementary School Journal, v. 87, n. 2, p. 117-138, 1986.

STAUB, F.; STERN, E. The nature of teachers' pedagogical content beliefs matters for students' achievement gains: Quasi-experimental evidence from elementary mathematics. Journal of Educational Psychology, v. 94, n. 2, p. 344-355, 2002.

STIPEK, D.; GIVVIN, K.; SALMON, J.; MACGYVERS, V. Teachers' beliefs and practices related to mathematics instruction. Teaching and Teacher Education, v. 17, n. 2, p. 213-226, 2001.

STRAUSS, S. Theories of learning and development for academics and educators. Educational Psychologist, v. 28, n. 3, p. 191-203, 1993.

. Confessions of a born-again structuralist. Educational Psychologist, v. 31, n. 1, p. 15-21, 1996.

; SHILONY, T. Teachers' models of children's minds and learning. In: HIRSCHFELD, L.; GELMAN, S. Mapping the mind: Domains pecificity in cognition and culture. Cambridge: Cambridge University Press, 1994. p. 455-473.

TABACHNICK, B.; ZEICHNER, K. The impact of the student teaching on the 
development of teacher perspectives. Journal of Teacher Education, v. 35, n. 6, p. 28-36, 1984.

TARDIF, M.; LESSARD, C. Le travail des enseignants au quotidien. Bruxelas: De Boeck, 1999.

TERHART, E. Lehrerberuf und Lehrerbildung. Weinheim: Beltz, 2001.

THOMPSON, A. Teachers' beliefs and conceptions: A synthesis of the research. In: GROWS, D. Handbook of research on mathematics teaching and learning. Nova York: MacMillan, 1992. p. 127-146.

TICKLE, L. New teachers and the emotions of learning teaching. Cambridge Journal of Education, v. 21, n. 3, p. 319-329, 1991.

TILEMA, H.; KNOL, W. Promoting student teacher learning through conceptual change or direct instruction. Teaching and Teacher Education, v. 13, n. 6, p. 579-595, 1997.

TOMANEK, D. A case of dilemmas: Exploring my assumptions about teaching science. Science Education, v. 78, n. 5, p. 399-414, 1994.

TVERSKY, A.; KAHNEMAN, D. Judgment under uncertainty: Heuristics and biases. Science, v. 185, n. 4157, p. 1124-1130, 1974.

VAN DRIEL, J.; BULTE, A. ; VERLOOP, N. The relationship between teacher's general beliefs about teaching and learning and their domain specific curricular beliefs. Learning and Instruction, v. 17, n. 2, p. 156-171, 2007.

VAN FLEET, A. Learning to teach: The cultural transmission analogy. Journal of Thought, v. 14, n. 4, p. 281-290, 1979.

VAUSE, A. Les croyances et connaissances des enseignants à propos de l'acte d'enseigner: vers un cadre d'analyse. Les Cahiers de Recherche en Éducation et Formation, n. 66, 2009.

VEENMAN, S. Perceived problems of beginning teachers. Review of Educational Research, v. 54, n. 2, p. 143-177, 1984.

VERLOOP, N.; VAN DRIEL, J.; MEIJER, P. Teacher knowledge and the knowledge base of teaching. International Journal of Educational Research, v. 35, n. 5, p. 441-461, 2001.

WAGNER, A. Conflicts in consciousness: Imperative cognitions can lead to 
knots in thinking. In: KOMPF, M.; DENICOLO, P. Teacher Thinking twenty years on: Revisiting persisting problems and advances in education. Lisse: Swets \& Zeitlinger B.V., 2003. p. 197-208.

WANLIN, P.; CRAHAY, M. La pensée des enseignants pendant l'interaction en classe. Éducation et didactique, 2012. Disponível em: 〈https:// educationdidactique.revues.org/1287>.

; LAFONTAINE, D.; CRAHAY, M. Les dilemmes dans la double cyclicité de la pensée planificatrice des enseignants. Revue Suisse des Sciences de l’Éducation, submetido para publicação.

WEINSTEIN, C. Preservice teachers' expectations about the first year of teaching. Teaching and Teacher Education, v. 4, n. 1, p. 31-40, 1988.

- Teacher education students' preconceptions of teaching. Journal of Teacher Education, v. 40, n. 2, p. 53-60, 1989.

WEINSTEIN, R.; MADISON, S.; KUKLINSKI, M. Raising expectations in schooling: Obstacles and opportunities for change. American Educational Research Journal, v. 32, n. 1, p. 121-159, 1995.

WILCOX, S.; SHRAM, P.; LAPPAN, G.; LANIER, P. The role of a learning community in changing preservice teachers' knowledge. East Lansing: Michigan State University, 1991.

WILSON, S. The secret garden of teacher education. Phi Delta Kappa, v. 72, n. 3, p. 204-209, 1990.

WILSON, W.; KATAYANI, M. Intergroup attitudes and strategies in games between opponents of the same or a different race. Journal of Personnality and Social Psychology, v. 9, n. 1, p. 24-30, 1968.

WINDSCHITL, M. Framing constructivism in practice as the negotiation of dilemmas: An analysis of the conceptual, pedagogical, cultural, and political challenges facing teachers. Review of Educational Research, v. 72, n. 2, p. 131175, 2002.

WINITZKY, N. Structure and process in thinking about classroom management: An exploratory study of prospective teachers. Teaching and Teacher Education, v. 8, n. 1, p. 1-14, 1992.

; KAUFCHAK, D. Constructivism in teacher education: Applying 
cognitive theory to teacher learning. In: RICHARDSON, V. Constructivist education: Building news understandings. Londres: Falmer Press, 1997. p. 5983.

WOOLFOLK HOY, A.; BURKE SPERO, R. Changes in teacher efficacy during the early years of teaching: A comparison of four measures. Teaching and Teacher Education, v. 21, n. 4, p. 343-356, 2005.

; MURPHY, P. Teaching educational psychology to the implicit mind. In: B. TORFF, B.; STERNBERG, R. Understanding and teaching the intuitive mind. Mahwah: Lawrence Erlbaum, 2001. p. 145-186.

; DAVIS, H.; PAPE, S. Teachers' knowledge and beliefs. In: ALEXANDER, P.; WINNE, P. Handbook of educational psychology. 2. ed. Mahwah: Lawrence Erlbaum, 2006. p. 715-737.

YILDIRIM, A. Instructional planning in a centralized school system: Lessons of a study among primary school teachers in Turkey. International Review of Education, v. 49, n. 5, p. 525-543, 2003.

ZAHORIK, J. Stability and flexibility in teaching. Teaching and Teacher Education, v. 6, n. 1, p. 69-80, 1990.

ZEICHNER, K.; TABACHNIK, R.; DENSMORE, K. Individual, institutional, and cultural influences on the development of the teachers' craft knowledge. In: CALDERHEAD, J. Exploring teacher thinking. Londres: Cassell, 1987. p. 21-59.

Sobre os autores:

Marcel Crahay é professor da Universidade de Genebra na área de desenvolvimento, aprendizagem e intervenção em situações escolares.

E-mail: marcel.crahay@unige.ch

Philippe Wanlin é professor da Universidade de Genebra na área de desenvolvimento, aprendizagem e intervenção em situações escolares.

E-mail: philippe.wanlin@unige.ch

Élisabeth Issaieva é professora da Universidade de Genebra na área de desenvolvimento, aprendizagem e intervenção em situações escolares.

E-mail: elisabeth.issaieva@unige.ch 
Isabelle Laduron é professora da Universidade de Liège na área de abordagens psicopedagógicas e aprendizagens escolares.

E-mail: isabelle.laduron@helha.be 